Linköping Studies in Science and Technology

Dissertation No. 2170

\title{
Science Parks and talent attraction: a study on the development of Science Parks
}

\section{Eduardo de Almeida Cadorin}

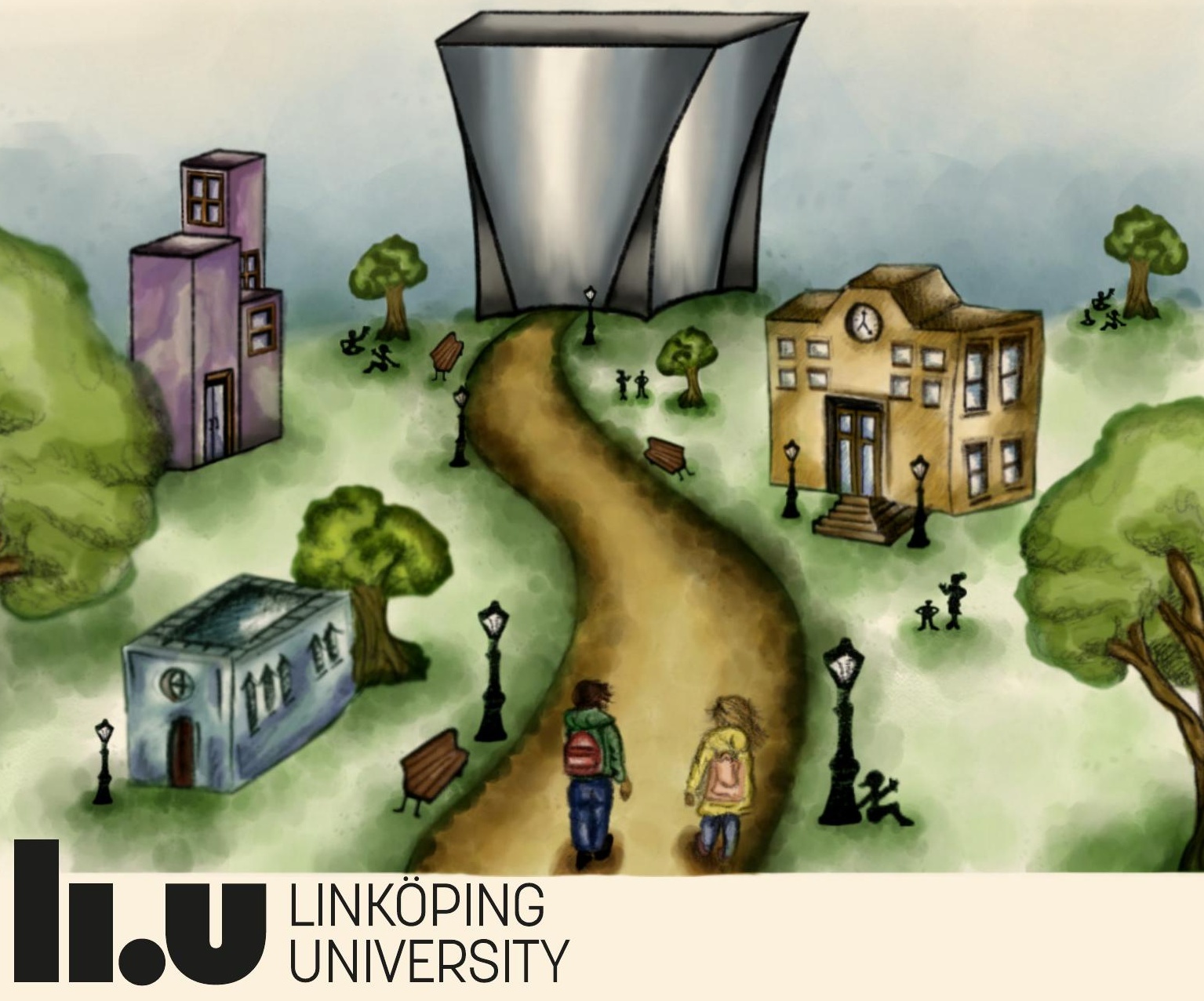



Linköping Studies in Science and Technology

Dissertations No. 2170

\title{
Science Parks and talent attraction:
}

a study on the development of Science Parks

\author{
Eduardo de Almeida Cadorin
}

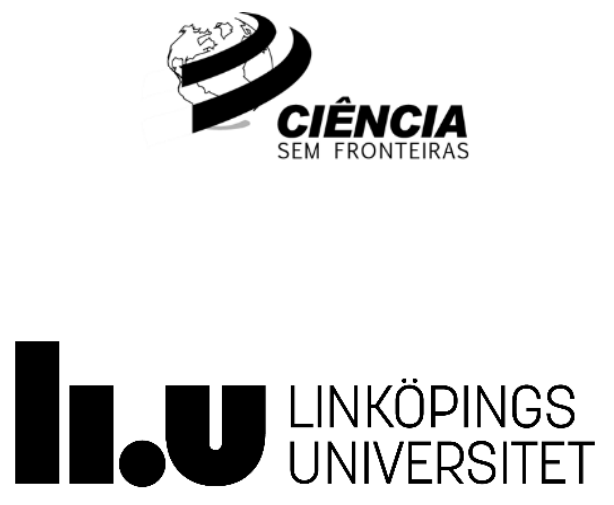

2021

Department of Management and Engineering Linköping University, SE-581 83 Linköping, Sweden 
Cover art by Giovana Baroni Cadorin and Giulia Baroni Cadorin

(C) Eduardo de Almeida Cadorin, 2021

Science Parks and talent attraction: a study on the development of Science Parks

Linköping Studies in Science and Technology, Dissertations, No. 2170

ISSN: 0345-7524

ISBN: 978-91-7929-023-8

Printed in Sweden by: LiU-Tryck, Linköping, 2021

Distributed by:

Linköping University

Department of Management and Engineering

SE-581 83 Linköping, Sweden

Tel: +4613281000 


\section{Abstract}

This dissertation investigates the development of Science Parks (SPs) from the perspective of talent attraction activities. Studies on SPs often address only traditional services that parks provide tenant firms. Thus, few studies have focused on activities organised by SPs to attract talent, and even fewer studies have considered the perspective of SP management (supply-side) rather than tenant firms (demand-side). This dissertation argues that the characteristics of the talent attracted to tenant firms and the SP's structure, processes, characteristics, and stakeholder relationships influence SP performance. In addition, the talent attraction activities developed by the SP mediate this influence.

This thesis relies on five papers, both qualitative and quantitative, written in collaboration with other scholars. This study shows that SPs organise talent attraction activities according to the characteristics of the desired talent and park configurations, such as their collaborations with stakeholders and the level of maturity of the tenant firms. These activities provide tenant firms with access to human resources suitable for their growth, contributing to the performance of the SP.

This study contributes to research on the development of SPs by shedding light on how talent attraction activities organised by SPs influence their development. Furthermore, this thesis presents talent attraction as a conceptual element and proposes a model that includes the influence of talent attraction in a supply-side perspective and as a mediator of SP performance.

Finally, this thesis recommends that SP managers support tenant firms of all maturity in the search for qualified professionals, facilitate the entry process of talents and firms from abroad, strengthen ties with the local university and student community and promote a creative, enterprising and innovative environment. 
Keywords: Science Parks, talent attraction, new technology-based firms, students, university, university-external collaboration, success factors. 


\section{Sammanfattning}

Avhandlingen studerar Science Parks (SPs) och deras aktiviteter för talangattrahering, med andra ord aktiviteter för att rekrytera talangfulla medarbetare. Studier om SPs berör traditionellt de generella tjänster som SPs erbjuder sina företag, vanligen nya teknikbaserade företag och organisationer. Däremot finns det få tidigare studier inom den akademiska litteraturen om processerna för att attrahera talanger, i synnerhet sådana där analysen mer utgår från SPs försörjningsperspektiv snarare än de lokaliserade företagen och organisationerna (efterfrågeperspektivet). Avhandlingen argumenterar för att flera faktorer påverkar SPs förmåga att attrahera talanger: dels de önskade kvalifikationerna hos medarbetarna, dels hur SPs egna strukturer, processer och intressenter påverkar arbetet. SPs egna aktiviteter för att attrahera talanger fungerar i sammanhanget även som en förmedlare mellan de enskilda företagen och organisationerna och deras potentiella medarbetare.

Avhandlingen baseras främst på fem publikationer, vilka är samförfattade med andra forskare och innehåller såväl kvalitativa som kvantitativa studier. De huvudsakliga resultaten är att SPs organiserar sina aktiviteter för att attrahera talanger dels utifrån de önskade medarbetaregenskaperna, dels efter mognaden hos de lokaliserade företagen. Samarbeten med olika intressenter ger också SPs företag tillgång till viktiga resurser och därmed möjlighet till tillväxt, vilket $\mathrm{i}$ sin tur bidrar till SPs prestation i den roll man har för att utveckla företagen, organisationer och samhället.

Avhandlingens främsta forskningsbidrag är dess analys av hur olika aktiviteter för talangattrahering påverkar SPs utveckling och följaktligen prestation. Talangattrahering introduceras $i$ avhandlingen som ett konceptuellt element och en modell utvecklas för talangattrahering både (i) ur ett försörjningsperspektiv och (ii) som en 
förmedlare av SPs prestation. Avhandlingen rekommenderar också att ledningen för SPs stödjer lokaliserade företag i sökandet efter skickliga medarbetare, det vill säga både stödjer företag och individer vilka kan ha särskilda behov och samarbetar med universitet för att exempelvis ge möjlighet till kurser och seminarier inom innovation och entreprenörskap. Detta ger även de lokaliserade företagens tillgång till talanger och kunskap vid universiteten och skapar dessutom en attraktiv omgivning för talangfulla medarbetare.

Nyckelord: Science Parks, talangattraktion, nya teknikbaserade företag, studenter, universitet, universitet-externt samverkan, framgångsfaktorer. 


\section{Acknowledgement}

This work would not be possible without the support of many people and organisations to whom I would like to express my great gratitude. First, I praise the Father for the gift of life. Without Him, nothing would be possible.

I am immensely grateful to my supervisor Magnus Klofsten for his precious guidance throughout this course, believing in my talent and encouraging me to evolve as a researcher. Also, I am extremely thankful to my assistant supervisor Hans Löfsten for all the immeasurable advice and teaching I received in preparing and publishing the quantitative studies and developing this thesis.

To the friends of PIE, I express my sincere thanks for the warm and friendly relationship during my time at LiU. Our pleasant and stimulating conversations in the corridors and in the traditional fredagsfika helped me grow as a researcher and get to know each of their countries a little bit. You all will always be a wonderful memory in my life.

Many thanks to those with whom I had the opportunity to develop this research and publish articles together, particularly Sten Gunnar Johansson, founder and former CEO of Linköping Science Park, Alberto Albahari, from Universidad de Málaga, Dzamila Bienkowska and Eloïse Germain-Alamartine, from Linköping University. Working with you was an enjoyable period with a lot of growth. I also thank all those who accepted to be interviewed throughout this research for their invaluable contribution.

My esteemed thanks to the entire IASP team, who made it possible for the survey to receive many quality responses from several European and Brazilian parks. 
This project would not be possible without the support of the Brazilian Army and the financial support of the $\mathrm{CNPq}^{1}$, through the Science Without Borders project. Many thanks to both of you. Pátria amada, Brasil!

I sincerely thank my parents for cultivating in me the desire to seek knowledge constantly.

Last but not least, all my gratitude to my beloved wife Michele and my sweet daughters Giovana and Giulia, of whom I am very proud. Without your support and understanding to accept changes in your lives, this research would not be possible. This thesis is also an achievement of yours.

Thank you all!

Eduardo de Almeida Cadorin, Linköping, 2021.

${ }^{1}$ This research received financial support from CNPq (National Council for Scientific and Technological Development), Brazil. 


\section{Table of Contents}

ABSTRACT ......................................................................................II

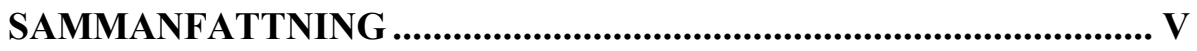

ACKNOWLEDGEMENT ........................................................... VII

TABLE OF CONTENTS ............................................................................. IX

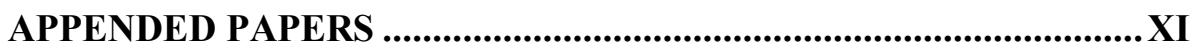

ADDITIONAL PAPERS ....................................................................

TABLE OF FIGURES ................................................................. XII

TABLE OF TABLES.......................................................................... XII

PART I: SYNTHESIS _.................................................................. 1

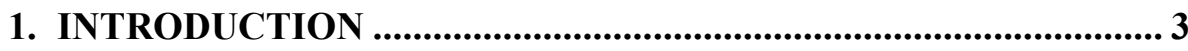

1.1. The ReleVAnce Of StUdying SCIENCE PARKS ....................................... 3

1.2. THE EMERGENCE OF SCIENCE PARKS........................................................... 4

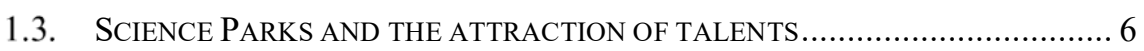

1.4. EXEMPLIFYING TALENT ATtRACTION ACtivity AT A SCIENCE PARK .......... 7

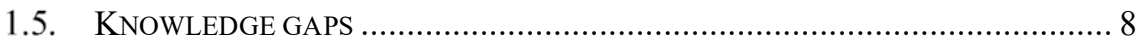

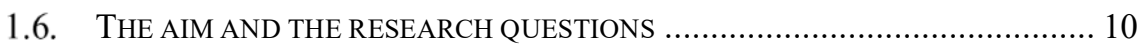

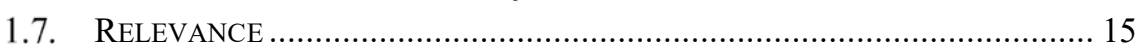

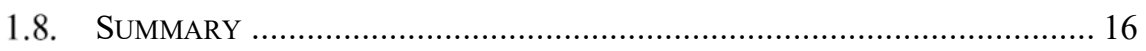

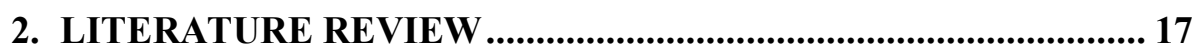

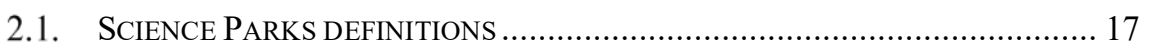

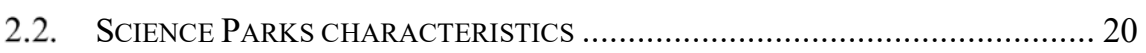

2.3. StRUCTURE AND PROCESSES OF SCIENCE PARKS .................................. 22

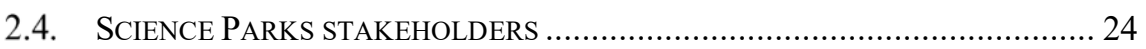

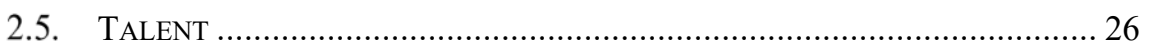

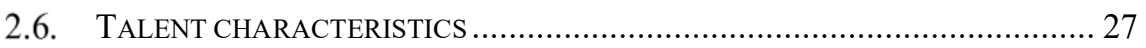

2.7. SCIENCE Park TALENT ATtRaction ACTIVITIES ........................................ 28

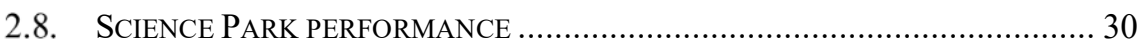

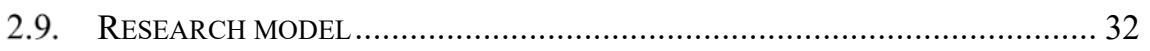

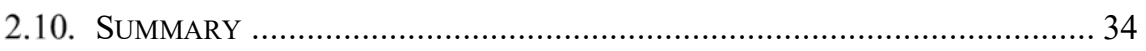

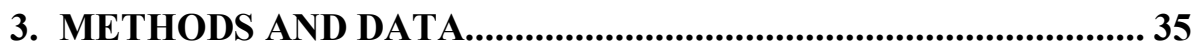

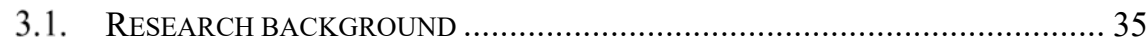

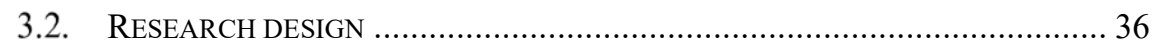

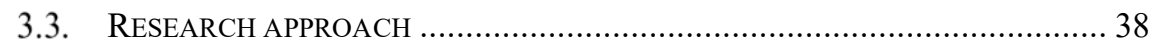




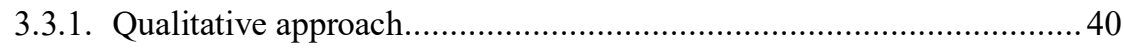

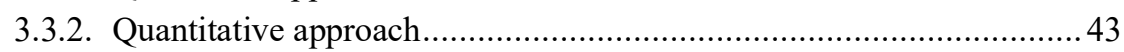

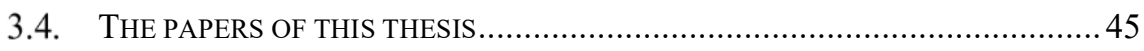

3.4.1. Paper 1: Future developments for Science Parks: Attracting and developing talent.

3.4.2. Paper 2: Science Parks and the attraction of talents: activities and challenges.

3.4.3. Paper 3: Universities and Science Parks: Engagements and interactions in developing and attracting talent.

3.4.4. Paper 4: Science Parks, talent attraction and stakeholder involvement: an international study

3.4.5. Paper 5: Science Parks and talent attraction management: university students as a strategic resource for innovation and entrepreneurship. .. 49

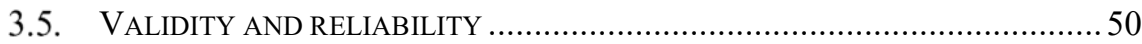

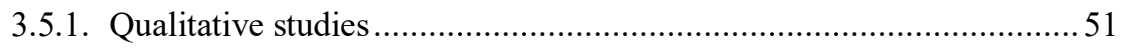

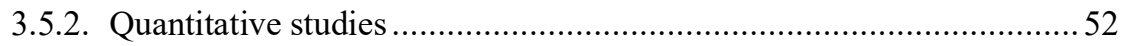

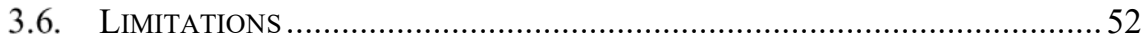

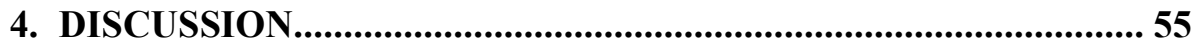

4.1. HOW SCIENCE PARKS ORgANISE TALENT ATtRACTION ACTIVITIES ........... 55

4.2. HOW DOES COLLABORATION WITH STAKEHOLDERS INFLUENCE SCIENCE PARKS PLANNING FOR TALENT ATTRACTION ACTIVITIES AND THEIR

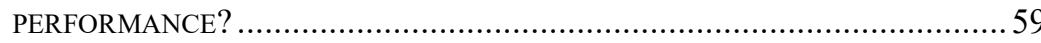

4.3. ImPLiCATIONS OF THE RESEARCH FINDINGS ON SCIENCE PARK TALENT ATTRACTION ACTIVITIES FOR RESEARCH AND PRACTICE ............................. 61

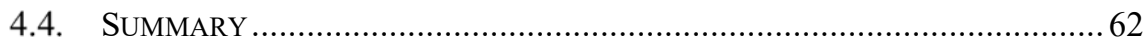

5. CONCLUSIONS AND FUTURE RESEARCH.............................. 67

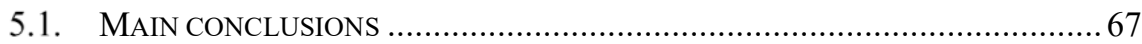

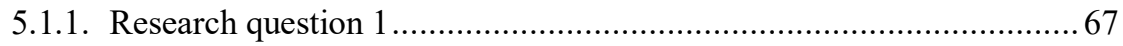

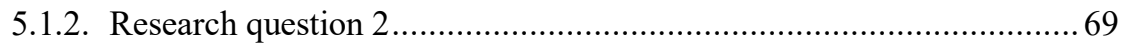

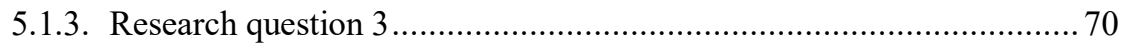

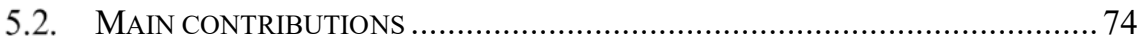

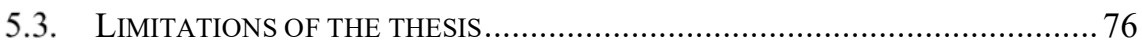

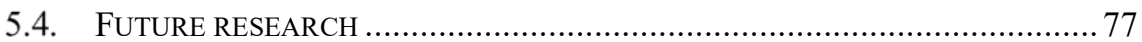

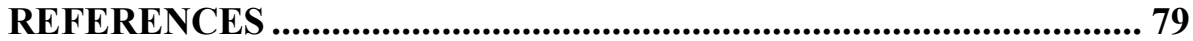

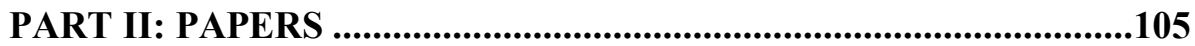




\section{Appended papers}

Paper 1: Cadorin, E., Johansson, S. G., \& Klofsten, M. (2017). Future developments for Science Parks: Attracting and developing talent. Industry and Higher Education, 31(3), 156-167.

Paper 2: Cadorin, E., Klofsten, M., Albahari, A., \& Etzkowitz, H. (2020).

Science Parks and the attraction of talents: activities and challenges. Triple Helix, 6(1), 36-68.

Paper 3: Cadorin, E., Germain-Alamartine, E., Bienkowska, D., \& Klofsten, M. (2019). Universities and Science Parks: Engagements and interactions in developing and attracting talent. In Developing Engaged and Entrepreneurial Universities (pp. 151-169). Singapore: Springer.

Paper 4: Cadorin, E., Klofsten, M., \& Löfsten, H. (2021). Science Parks, talent attraction and stakeholder involvement: an international study. Journal of Technology Transfer, 46(1), 1-28.

Paper 5: Löfsten, H., Klofsten, M., \& Cadorin, E. (2020). Science Parks and talent attraction management: university students as a strategic resource for innovation and entrepreneurship. European Planning Studies, 28(12), 2465-2488.

\section{Additional papers}

Cadorin, E., Klofsten, M., \& Johansson, S. G. (2017). The development of a modern Science Park: A Swedish good practise. Revista Militar de Ciência e Tecnologia, 34, 55-59.

Klofsten, M., Norrman, C., Cadorin, E., \& Löfsten, H. (2020). Support and development of small and new firms in rural areas: a case study of three regional initiatives. SN Applied Sciences, 2, 1-9. 


\section{Table of Figures}

FIGURE 1 - RESEARCH MODEL: THE EFFECTS OF TALENT ATTRACTION ACTIVITIES ON SCIENCE PARK PERFORMANCE.

\section{Table of Tables}

TABLE 1 - RELATION BETWEEN RESEARCH QUESTIONS AND PAPERS ......... 14

TABLE 2 - DEFINITIONS FROM SCIENCE PARK ASSOCIATIONS.................... 19

TABLE 3 - THE MAIN CHARACTERISTICS OF TALENTS ................................. 28

TABLE 4 - PHASES OF THE RESEARCH DESIGN …….................................. 37

TABLE 5 - AIM AND RESEARCH APPROACH OF THE PAPERS........................ 39

TABLE 6 - THE THREE RESEARCH QUESTIONS AND EMPIRICAL FINDINGS. .. 63 
PART I: SYNTHESIS 


\section{INTRODUCTION}

This chapter provides the background to this study by discussing Science Parks and talent attraction activities. First, this introduction outlines the relevance of studying Science Parks and how their concept has evolved. Second, this chapter discusses the context in which Science Parks develop activities to attract talent. Third, this chapter identifies potential knowledge gaps in the literature. Fourth, this chapter presents the aim of the thesis and the research questions. Finally, the chapter presents how the thesis is relevant for research and practice.

\subsection{The relevance of studying Science Parks}

Science Parks support the emergence and development of technologybased firms by providing infrastructure and services (Colombo \& Delmastro, 2002; Díez-Vial \& Montoro-Sanchez, 2017). In recent decades, scholars have carried out many studies on the relevance, networks, and performance of Science Parks, mainly from the perspective of the tenant firms (Löfsten \& Lindelöf, 2002; RamírezAlesón \& Fernández-Olmos, 2018).

Since most firms in Science Parks are technology-based which depend heavily on access to skilled workers, researchers have started to study the ability of Science Parks to develop mechanisms to tailor solutions for attracting talent (Bellavista \& Sanz, 2009; Chen \& Yu, 2008; Roldan et al., 2018). Such solutions may involve attracting people with specific knowledge who can facilitate the establishment and development of firms (Gwebu et al., 2018) or attract individuals with general qualifications but great potential to develop their professional skills, such as university students (Tansley \& Kirk, 2017).

Universities are a relevant source of knowledge and technology for business innovations (Bozeman, 2000; Cohen et al., 2002; Guerrero \& Berbegal-Mirabent, 2016; Salter \& Martin, 2001). A greater emphasis 
on the third mission of universities (see Gulbrandsen \& Slipersæter, 2007) has made the transfer of technology and knowledge from universities to industry extremely relevant (Bozeman, 2000; Minguillo $\&$ Thelwall, 2015). In addition, the local university generates an annual flow of graduates (Cai \& Liu, 2015; Cowling \& Lee, 2017; Etzkowitz, 2008; Florida, 1999; Kusmana, 2019), promoting the formation of a pool of highly qualified professionals in Science Parks (Cadorin et al., 2020; Eckardt, 2017).

Talent attraction activities need to be developed to attract professionals who have the characteristics to meet the needs of the tenant firms. These activities should simplify the talent management processes of firms, offering them more agile means of obtaining the desired expertise. In addition to the characteristics of the talents, Science Park features such as infrastructure, processes, and stakeholders can contribute to the planning and execution of the talent attraction activities (Löfsten et al., 2020).

\subsection{The emergence of Science Parks}

The Science Park concept was originated as an unplanned consequence of a land capitalisation arrangement to raise funds to support the academic development of Stanford University (Etzkowitz \& Zhou, 2018; Gillmor, 2004). However, firms moving into Stanford's Industrial Park in the 1960s were not typical manufacturing firms, but firms created by researchers associated with the university who wanted their enterprises to remain closely connected to the source of their ideas and people (Etzkowitz \& Zhou, 2018). In the late 1970s and early 1980s in the United States, conditions were favourable for establishing commercial partnerships between universities and firms as a result of various political initiatives, such as the Bayh-Dole Act (Link \& Scott, 2006; Sun et al., 2019). 
The first generation of Science Parks focused on providing office spaces and production areas near local universities (Rowe, 2014). The concept of knowledge sharing associated with geographical proximity between participants provides ideas and directions for university research and competitive benefits for firms. The proximity to different sources of knowledge, whether tacit or codified, generates many opportunities to create and acquire knowledge and makes the innovation process more efficient (Link \& Scott, 2018).

To serve tenants properly, Science Parks need to find a balance between support oriented to configuration and process (Albahari et al., 2011, 2019; Autio \& Klofsten, 1998) as land will become more than a soil platform of human activity. That is, land can be seen as a set of systems that provide the infrastructure required for business development. Moreover, high-tech knowledge-based development emanates from a variety of private and public capital such as venture, seed, angel, and hedge capital (Wilson et al., 2018). In addition, the labour market no longer only rewards physical activity but has become increasingly knowledge-intensive and more interested in highly qualified workers (Moussa et al., 2017; Svensson et al., 2012).

Indeed, Science Parks moved from a single purpose organisational model to a multifaceted and interactive organisational mode with a set of responsibilities and more complex relationships (Etzkowitz \& Zhou, 2018), which also contribute to the internal processes of tenant firms. In modern versions, Science Parks introduce some new business support mechanisms such as talent attraction activities (Cadorin et al., 2020). Creative and entrepreneurial environments, spaces for events and meetings, and green and leisure areas such as cafes and clubs also contribute to the emergence of new ventures and the attraction of talent (Florida \& Mellander, 2015). A Science Park's brand, built mainly through social networks, the internet, and social media, is one of the most valuable assets delivered to tenants (Cadorin, Johansson, et al., 2017; Lam et al., 2021; Salvador, 2011). 


\subsection{Science Parks and the attraction of talents}

In the literature, Science Parks are seen as drivers for converting scientific research into technological innovation as they "can provide the catalytic incubator environment for the transformation of "pure" research into production' (Westhead, 1997, p. 46). Recent developments have led the concept of Science Parks away from its academic origins toward a view that sees them as seedbeds of innovation ventures (Lamperti et al., 2017; Squicciarini, 2009) and attractors of technology-based firms and skilled professionals (Guadix et al., 2016).

The influence of firms' physical and organisational capital resources on competitiveness has diminished due to technological advances that have increased the speed and efficiency of information disclosure. That is, human capital has become a differentiating element and the main driver of a firm's competitiveness (Alnidawi et al., 2017; J. Barney, 1991; Holland et al., 2007).

Moreover, the level of maturity of firms implies different human resource needs. This thesis does not define the maturity level of a firm in terms of firm size (Bulan and Yan 2010) but in terms of (i) the number of years of operation (Gilley et al., 2004), (ii) the ability to manage external resources (Davidsson \& Klofsten, 2003), and (iii) the development level of the business platform (Klofsten, 1994). Whereas mature firms look for innovative ideas to improve their production processes, which is accomplished by hiring young-minded professionals such as university students (Klofsten \& Jones-Evans, 1996; Lamperti et al., 2017), younger firms often lack managerial or technical competence in the team (Bøllingtoft \& Ulhøi, 2005; De Cleyn et al., 2015), and need to recruit professionals with specific skills such as IT personnel, managers, and CEOs (De Cleyn et al., 2015; Zhu \& Tann, 2005). Furthermore, young firms often have a limited network of contacts, making it challenging for them to find the necessary 
professionals (De Cleyn et al., 2015). In fact, lack of maturity can make it challenging to identify what skills they lack.

\subsection{Exemplifying talent attraction activity at a Science Park}

Lindholmen Science Park (LSP) in Gothenburg was founded in 2000 and is closely located to Chalmers University of Technology and the University of Gothenburg. LSP has about 350 firms and 11000 employees, and its main competence areas are transport, ICT, and media industries. In 2013, Geely Auto, a Chinese firm, started a centre for future cars - China Euro Vehicle Technology (CEVT) - as a joint R\&D centre with Volvo Cars at LSP. This new centre intends to develop vehicle modules and components that can be used by Geely Auto and Volvo Cars, companies that belong to the Zhejiang Geely Holding Group. In 2020, CEVT employed around 2000 workers. ${ }^{2}$

Interviews with the LSP's CEO made it evident that the CEVT had special features making it worthy of further investigation: the CEVT involves two countries with totally different cultures (i.e., China and Sweden); the CEVT involves two car manufacturers with distinct histories (i.e., Geely Auto and Volvo Cars); and the CVET has a special workforce (i.e., a mix of Swedish and Chinese workers who have moved to live and work in Sweden). To welcome CEVT and create favourable conditions for a long-lasting presence in Sweden, LSP focused on creating a stable situation regarding the recruitment and development of a competent workforce. The Science Park provided network services that help integrate CEVT workers into the Swedish system, including immigration assistance, housing, schools, networks, and contacts with the Swedish bureaucracy. LSP also brought the

${ }^{2}$ https://www.cevt.se/who-we-are/\#management 
CEVT and Swedish universities closer together to make the recruitment of students and researchers more straightforward, to establish research links, and to transfer more effectively knowledge and technology. The CEVT case demonstrates how a Science Park could be attractive, creating a suitable environment for the settling foreign professionals and for the development of a large firm, which usually is less dependent on park support.

\subsection{Knowledge gaps}

Researchers, park managers, and policymakers have a strong interest in Science Parks as promoters of innovation, entrepreneurship, and regional development. However, studies often address the more traditional services offered to tenant firms, and their analyses are usually based on the contribution that Science Parks make to the development and success of their firms and typically only from the perspective of the firms receiving the services (Gwebu et al., 2018; Lindelöf \& Löfsten, 2003; Monck et al., 1998; Ramírez-Alesón \& Fernández-Olmos, 2018; Westhead, 1997).

Therefore, there are potential gaps in knowledge regarding other forms of support services provided by Science Parks besides those popularly known and disseminated. The processes developed by Science Parks to attract talent to facilitate corporate human resource management are rarely explored in the literature (Bellavista \& Sanz, 2009; Roldan et al., 2018), and even fewer analyses consider the perspective of park management (supply-side) rather than park tenants firms and their entrepreneurs (demand-side) (Albahari et al., 2011, 2019). That is, two knowledge gaps were identified: the mechanisms through which Science Parks support tenant firms and the perspective frequently adopted in studies conducted on Science Parks.

Science Parks are tools in an economic development environment (Luger \& Goldstein, 1991; Poonjan \& Tanner, 2019). They facilitate 
firm-university connections (Colombo \& Delmastro, 2002; Felsenstein, 1994; Fukugawa, 2006; Minguillo \& Thelwall, 2015; Vedovello, 1997; Westhead \& Storey, 1995) and provide business consulting and the infrastructure firms need to operate (Albahari et al., 2019; Colombo \& Delmastro, 2002; Monck et al., 1998). In addition, Science Parks provide complementary advantages such as meeting places and leisure and green areas, which contribute to creating an ideal location for the development of firms. However, the portfolio of activities performed by Science Parks is much more extensive than usually presented in the literature and other ways of supporting firms have been developed and practised. With business globalisation and rapid access to information, knowledge has become a firm's primary asset, an understanding that recognises the value of skilled workers (Alnidawi et al., 2017; J. Barney, 1991; Holland et al., 2007). Thus, knowledge of the factors that influence the planning and execution of talent attraction activities needs to be deepened and better understood.

Some studies compare the performance of firms inside and outside Science Parks (Link, 2016; Löfsten \& Lindelöf, 2002; Massey et al., 2003; Schiavone et al., 2014). Other studies focus on how firms perceive the benefits of the services offered by Science Parks and how such benefits influence the development and success of the firms (DíezVial \& Fernández-Olmos, 2017; Sadeghi \& Sadabadi, 2015).

The vast majority of studies that assess the benefits offered by Science Parks collect and analyse data from the perspective of tenant firms that are the recipients of park support services (Díez-Vial \& FernándezOlmos, 2017; Löfsten \& Lindelöf, 2002; Monck et al., 1998). Therefore, these studies evaluate only the processes developed by Science Parks that directly target a particular firm or group of firms. In addition, as firms can evaluate only the result of these processes, these studies can report only the firms' perception of what was delivered to them. When analysing the activities developed by Science Parks only from the perspective of the service recipients, studies miss the 
opportunity to assess the collective progress and how much each process contributed, directly or indirectly, to the growth of the Science Park as a whole. In fact, the success of Science Parks is strongly correlated with the success of each tenant firm, but the reverse is not always true.

When it comes to talent attraction processes developed by Science Parks, studies become even more scarce (Bellavista \& Sanz, 2009; Roldan et al., 2018). Talent attraction activities do not necessarily focus on supplying the needs of a particular firm or group of firms directly but may aim to strengthen the Science Park brand and make the environment more attractive for talent and firms (Cadorin, Johansson, et al., 2017; Lam et al., 2021; Salvador, 2011).

Therefore, this research project adopts the perspective of the Science Park (organisational level) rather than the perspective of individuals or tenant firms (individual or firm level) to cover this little-explored gap in the Science Park and talent attraction literature.

\subsection{The aim and the research questions}

This study analyses the development of Science Parks from the perspective of park management's activities that relate to attracting talent. Potential knowledge gaps in the Science Park literature provide the basis for formulating the objective of this thesis:

To explore how Science Parks plan and perform activities to attract talent to the park and its tenant firms.

Science Parks have undergone several transformations over the years, moving from a land-oriented organisational model to becoming a more interactive organisation with much more complex roles and relationships (Etzkowitz \& Zhou, 2018). In this new scenario, Science Parks need to provide, in addition to space and infrastructure, 
mechanisms and opportunities for firms to capture knowledge, technology, and talent from the local university (Bellavista \& Sanz, 2009; Roldan et al., 2018).

Talents are individuals who have the skills, knowledge, creativity, professional competence, communication, and leadership ability (Saddozai et al., 2017) that make them capable of adding value to a firm, leading it to a higher level of performance (Mcdonnell et al., 2017; Thunnissen et al., 2013). Therefore, talent can be considered one of the critical resources needed for the development and growth of firms (Alnidawi et al., 2017; J. Barney, 1991; Holland et al., 2007).

In fact, studies have found a positive correlation between the performance levels of tenant firms and informal connections and talent mobility (Hu, 2008; Schweer et al., 2012). Moreover, this correlation is a result of proximity to a local university and the industrial region as well as the activities performed by Science Parks (Kakko, 2012). Although there is a vast literature on Science Parks (see literature review in Poonjan \& Tanner, 2019) and the importance of attracting talent is unanimous among researchers and park managers, little is known about these talent attraction activities that take place in Parks (Koh et al., 2005). Therefore, it is crucial to understand how Science Parks organise talent attraction activities and whether these activities are conducted in collaboration with local actors. Hence, the first research question is as follows:

\section{RQ1: How do Science Parks organise talent attraction activities, either on their own or in collaboration with stakeholders?}

Science Parks provide services that firms find difficult to offer internally in collaboration with other stakeholders. They build a network with tenant firms, universities, and research centres, 
supporting the exchange of knowledge (Albahari et al., 2017) and the talent attraction processes (Cadorin et al., 2021).

Universities play an essential role in the economic and social development of the regions in which they are located (Huffman \& Quigley, 2002; Mellander \& Florida, 2011; Youtie \& Shapira, 2008). Places close to world-class universities, such as Silicon Valley, Singapore, and Cambridge, are often sources of technology start-ups, mainly because having access to knowledge and talented professionals and students is a determining factor in developing innovative businesses and products (Cooke, 2007). Universities are the primary source of talent, providing a steady flow of graduating students (Cai \& Liu, 2015; Cowling \& Lee, 2017; Etzkowitz, 2008; Florida, 1999; Kusmana, 2019). Therefore, creating informal and formal cooperation with universities is a necessary and crucial decision for developing a Science Park and its tenant firms (Berbegal-Mirabent et al., 2015; Cadorin et al., 2019; $\mathrm{Hu}, 2008)$.

Also, considering that most Science Parks firms are technology-based, they rely on reaching qualified professionals. Thus, new studies on Science Parks have begun to address issues related to their ability to develop solutions that can attract talent to their tenants (Bellavista \& Sanz, 2009; Chen \& Yu, 2008; Roldan et al., 2018). Therefore, it is crucial to identify and qualify the types of interactions and collaborations occurring between Science Parks and their stakeholders (such as nearby universities) and to understand their influence in the planning and execution of the talent attraction activities undertaken by Science Parks. The second research question addresses this subject:

RQ2: How does collaboration with stakeholders influence Science Parks planning for talent attraction activities and their performance? 
Furthermore, efficient talent management practices can improve a firm's performance, and the activities of Science Parks can have a positive effect on a firm's performance (Huang et al., 2012; Löfsten \& Lindelöf, 2002; D. S. Siegel et al., 2003; Squicciarini, 2008, 2009; Vásquez-Urriago et al., 2014).

Indeed, talent-related activities developed by Science Parks can be tools to improve the performance of tenant firms. Talent management practices, which include attracting, selecting, developing, and retaining talent (Heinen \& O'Neill, 2004; Mcdonnell et al., 2017; Thunnissen et al., 2013), can create a competitive advantage for tenant firms (Ashton \& Morton, 2005; Heinen \& O’Neill, 2004). Science Parks should tailor talent activities to the needs of tenant firms. For example, start-ups need support that protects them from the high risk of failure during their first few years of operations (Bergek \& Norrman, 2015).

Because Science Parks involve relationships with a large number of actors, it is essential to recognise policy implications that guide the creation of formal and informal networks of interactions. Indeed, policy implications generated by studies help all those involved in Science Park development improve their planning and actions and stimulate their growth (Albahari et al., 2019; Harper \& Georghiou, 2005; Vedovello, 1997).

Finally, this thesis aims to propose recommendations for improving policies that will allow park managers to create a steady inflow of talent into the Science Park and researchers to develop studies to deepen knowledge on Science Park development and talent attraction activities. The third research question addresses this aim.

RQ3: What are the implications of the research findings on Science Park talent attraction activities for research and practice? 
Table 1 presents how the three research questions are correlated to the five papers that form this thesis. The "X" means that the research question was treated in the paper. Research Question 1 was addressed in Papers 1, 2, and 3, and Research Question 2 was addressed in Papers 3, 4, and 5. Finally, Research Question 3 was discussed in all five papers. Papers 1, 2, and 3 were qualitative case studies aimed at uncovering a deeper understanding of the talent activities undertaken by Science Parks. Papers 4 and 5, quantitative analyses of an international survey, were aimed at complementing the knowledge gained from case studies by seeking to understand how stakeholders and talent characteristics influence performance and Science Park talent activities.

Table 1 - Relation between research questions and papers

\begin{tabular}{|l|l|l|l|l|l|}
\hline \multirow{2}{*}{ Research questions } & \multicolumn{3}{|l|}{$\begin{array}{l}\text { Papers } \\
\text { (See the list below) }\end{array}$} \\
\cline { 2 - 6 } & 1 & 2 & 3 & 4 & 5 \\
\hline $\begin{array}{l}\text { RQ1: How do Science Parks organise talent } \\
\text { attraction activities, either on their own or in } \\
\text { collaboration with stakeholders? }\end{array}$ & $\mathrm{X}$ & $\mathrm{X}$ & $\mathrm{X}$ & & \\
\hline $\begin{array}{l}\text { RQ2: How does collaboration with } \\
\text { stakeholders influence Science Parks planning } \\
\text { for talent attraction activities and their } \\
\text { performance? }\end{array}$ & & & $\mathrm{X}$ & $\mathrm{X}$ & $\mathrm{X}$ \\
\hline $\begin{array}{l}\text { RQ3: What are the implications of the research } \\
\text { findings on Science Park talent attraction }\end{array}$ & $\mathrm{X}$ & $\mathrm{X}$ & $\mathrm{X}$ & $\mathrm{X}$ & $\mathrm{X}$ \\
activities for research and practice? & & & & & \\
\hline
\end{tabular}

Paper 1: Cadorin, E., Johansson, S. G., \& Klofsten, M. (2017). Future developments for Science Parks: Attracting and developing talent. Industry and Higher Education, 31(3), 156-167. 
Paper 2: Cadorin, E., Klofsten, M., Albahari, A., \& Etzkowitz, H. (2020).

Science Parks and the attraction of talents: activities and challenges.

Triple Helix, 6(1), 36-68.

Paper 3: Cadorin, E., Germain-Alamartine, E., Bienkowska, D., \& Klofsten,

M. (2019). Universities and Science Parks: Engagements and interactions in developing and attracting talent. In Developing Engaged and Entrepreneurial Universities (pp. 151-169). Singapore: Springer.

Paper 4: Cadorin, E., Klofsten, M., \& Löfsten, H. (2021). Science Parks, talent attraction and stakeholder involvement: an international study. Journal of Technology Transfer, 46(1), 1-28.

Paper 5: Löfsten, H., Klofsten, M., \& Cadorin, E. (2020). Science Parks and talent attraction management: university students as a strategic resource for innovation and entrepreneurship. European Planning Studies, 28(12), 2465-2488.

\subsection{Relevance}

Most existing studies analyse Science Park activities from the perspective of tenant firms by trying to understand how these firms perceive the value of the support received (Lindelöf \& Löfsten, 2003; Squicciarini, 2009; Vasquez-Urriago et al., 2016; Vásquez-Urriago et al., 2014). Therefore, in adding to the academic literature in this area, this study adopts a Science Park perspective (supply-side) and includes the attraction of talent as an essential element among the mechanisms adopted by Science Parks to generate value for tenant firms.

For practitioners, this study will help Science Park managers understand how and why they should optimise their activities to strengthen meaningful relationships such as with the government, local university, and student communities. This study also proposes to all those involved in the management and development of Science Parks how to support, in matters of talent, mature firms, which are often selfsufficient, and growing firms, which are usually more dependent on external support. 


\subsection{Summary}

Science parks support the emergence and development of technologybased firms, which depend heavily on access to skilled workers by providing infrastructure and services (Colombo \& Delmastro, 2002; Díez-Vial \& Montoro-Sanchez, 2017). Analysing the literature on Science Parks development, two potential gaps in knowledge were identified: the mechanisms through which Science Parks support tenant firms and the perspective frequently adopted in studies conducted on Science Parks. These gaps provide the basis for formulating the objective of this thesis, which is to explore how Science Parks plan and perform activities to attract talent to the park and its tenant firms. 


\section{LITERATURE REVIEW}

This chapter reviews the literature relevant to this thesis, starting with an overview of how the literature defines Science Parks, including their characteristics, structures, processes, and stakeholders. Then, a literature review is conducted, addressing definitions and characteristics associated with talent. Next, the support activities developed by Science Parks are contextualised within the scope of attracting talent. The literature is also examined to understand the factors that contribute to improving the performance of Science Parks. Finally, a proposal for a research model is detailed.

\subsection{Science Parks definitions}

The literature provides neither a widely accepted definition of Science Parks (Fukugawa, 2006; Hobbs et al., 2017) nor a clear understanding of their role in the region where they are located (Almeida et al., 2020). Also, several terms are used to indicate the types of parks, such as Science and Technology Parks, Research Parks, Innovation Parks, Innovation Centres, and Business Parks (Monck et al., 1998; Rowe, 2014). Also, Albahari et al. (2017) categorise Science Parks into four types: i) pure Science Parks, where a university is the principal owner; ii) Mixed Parks, where a university is a minority part-owner; iii) Technology Parks with a university, where the university is not a shareholder but has facilities at the park; and iv) Pure Technology Parks, where there is no university formally involved.

In addition, Escorsa and Valls (1996) note some differences between Research Parks, Technology Parks, and Science Parks regarding their operational focus and the presence of research institutions. According to these authors, Research Parks use teaching and research institutions to bring the academy closer to applied research without focusing on the development of new products and markets. Technology Parks focus on the generation of high-tech commercial products and do not consider 
the existence of a teaching or research centre to be relevant. Finally, Science Parks benefit from the presence of universities or research centres as they help generate and develop knowledge-based firms.

For Guadix et al. (2016), Science Parks, unlike other parks, have detailed policies for selecting tenant firms, participate in technology transfer processes, cooperate with actors from the public and private sectors, provide commercial support services, and offer incubators.

The location where the Science Parks are being studied also influence how they are named. Europe, Asia, and the United States typically use the terms Science, Technology, and Research, respectively, to refer to such parks. In addition, these regions have different relationships with Science Parks. In the United States, public sector involvement is usually indirect and focused on university research. In several Asian countries, government involvement is straightforward. In the United Kingdom, Science Parks are located very close to universities, whereas in the United States the distance between a Science Park and the university can vary since the space required is not always available nearby (Link \& Scott, 2018).

Albahari et al. (2010) found that the definitions of Science Parks commonly found in the literature are derived from three specialised organisations: the Association of Universities and Research Parks (AURP), the International Association of Science Parks and Areas of Innovation (IASP), and the United Kingdom Science Parks Association (UKSPA). These three definitions (see Table 2) provide insights into how practitioners view the organisation and purpose of Science Parks.

The common point in the definitions of the Science Park associations is that they all consider Science Parks to have infrastructures that facilitate innovation and promote the exchange of knowledge, with the university being one of the motivators of these interactions (Hobbs et al., 2017). 
Table 2 - Definitions from Science Park associations

\section{Organisation Definition}

AURP "University Research Parks are physical
environments that can generate, attract, and retain
science and technology firms and talent in alignment
with sponsoring research institutions that include
universities, as well as public, private and federal
research laboratories. Research Parks enable the flow
of ideas between innovation generators such as
universities, federal labs, and non-profit R\&D
institutions and firms located in both the Research
Park and the surrounding region" (AURP, 2017).

IASP

"A Science Park is an organisation managed by specialised professionals whose main aim is to increase the wealth of its community by promoting the culture of innovation and the competitiveness of its associated businesses and knowledge-based institutions.

To enable these goals to be met, a Science Park stimulates and manages the flow of knowledge and technology amongst universities, R\&D institutions, firms and markets; it facilitates the creation and growth of innovation-based firms through incubation and spin-off processes; and provides other valueadded services together with high-quality space and facilities" (IASP, 2017).

UKSPA

"A Science Park is a business support and technology transfer initiative that:

encourages and supports the start-up and incubation of innovation-led, high-growth, knowledge-based businesses;

provides an environment where larger and international businesses can develop specific and close interactions with a particular centre of knowledge creation for their mutual benefit; 
has formal and operational links with centres of knowledge creation such as universities, higher education institutes and research organisations" (UKSPA, 2017).

Finally, due to many definitions in the literature and the difficulty in having a widely accepted definition, this study uses the different definitions of Science Parks in the academic literature to define Science Parks. Here, Science Parks are understood to have a management team committed to stimulating innovative businesses and supporting the growth of tenant firms by offering physical resources, business advice, and services related to financial and marketing and connections with knowledge-generating institutions, such as universities and research centres to facilitate the transfer of technology and skilled human resources (Almeida et al., 2020; Colombo \& Delmastro, 2002; DiezVial \& Fernández-Olmos, 2017; Gyurkovics et al., 2014; Hansson, 2007; Monck et al., 1998).

\subsection{Science Parks characteristics}

Science Parks are policy-driven organisations (Huang et al., 2012), and their proliferation around the world is due to governments considering parks as a technology and innovation policy tool (Albahari et al., 2017; Squicciarini, 2008). Thus, since they are created in this planned and motivated way, the analysis of their characteristics is favoured, which would be more challenging to do with spontaneous agglomerations (Albahari et al., 2018).

The literature notes that age and size are usually associated with organisational performance (Blau, 1970; Huselid, 1995; Lu et al., 2015). Moreover, the creation date and physical size of Science Parks are easily ascertained. Park size is correlated with the number and maturity of tenant firms and the number of employees (Albahari et al., 2018; Autio \& Klofsten, 1998). 
Another characteristic that differentiates parks from other agglomerations is the presence of a management team that actively handles the park's activities (Albahari et al., 2018, 2019; Löfsten \& Lindelöf, 2002). Indeed, an experienced and committed management team is usually associated with successful Science Parks (Albahari et al., 2018; Cabral, 1998; Löfsten \& Lindelöf, 2002).

Albahari et al. (2018) correlate the age and the management team of parks; that is, due to accumulated knowledge, managers of older Science Parks can better understand the needs of tenant firms, so they can offer better support activities for tenants. In addition, Albahari et al. (2018) point out that the impact of business support takes time before it can be assessed and measured. It is worth highlighting that, considering the long term, there is a risk of stagnation of learning and accommodation in the execution of activities, which could decrease performance (Durand \& Coeurderoy, 2001).

Moreover, considering that parks are tools for developing innovation and technology and are geographically delimited, their location is also a relevant characteristic. In technologically developed regions, firms can find the connections and resources necessary for their development outside the Science Park; however, competition is more significant in these areas. On the other hand, in remote regions, the support of Science Parks is more critical for tenant firms, and they tend to stand out from local competitors as competition is reduced (Albahari et al., 2018; Felsenstein, 1994).

A park's proximity to universities and research centres means that a park will likely specialise in the same areas of knowledge as this approach will increase opportunities for knowledge creation and acquisition (Link \& Scott, 2018), knowledge spill over, and specialised labour recruitment (Albahari et al., 2019). Studies (Hu, 2008; Poonjan $\&$ Tanner, 2019) also point out that the proximity of Science Parks to universities and research centres increases the interaction between high- 
tech professionals and expands their professional networks. Moreover, the proximity between tenants often encourages interactions, positively influencing performance (Beaudry \& Swann, 2009; McCann \& Folta, 2011; Silva et al., 2020), although they can perceive this influence to different degrees (Jonsson, 2002).

Arthur (1990, p. 237) notes that the 'benefits to being in a location together with other firms increase with the number of firms in the location'; moreover, as the number of tenants increases, knowledge and social capital increase (Albahari et al., 2018), further attracting new firms and new talent. However, this effect only occurs once a certain threshold has been reached, and the effect might even diminish if the agglomeration becomes too large (Bakouros et al., 2002; Folta et al., 2006).

\subsection{Structure and processes of Science Parks}

Several studies analyse the effectiveness of Science Parks in promoting tenant firm's growth. Some authors argue that there are no benefits for tenant firms in comparison with off-park firms (Colombo \& Delmastro, 2002; Löfsten \& Lindelöf, 2002; e.g. Westhead, 1997). Other authors, however, perceive Science Park as drivers of innovation (e.g. Squicciarini, 2008, 2009; Vásquez-Urriago et al., 2014; Yang et al., 2009) as they can provide adequate structure and process for connecting tenants and academia, which facilitate contacts and partnerships that would be more difficult for firms to achieve on their own (Albahari et al., 2018; S. Gower \& Harris, 1996; S. M. Gower \& Harris, 1994; Vedovello, 1997).

Indeed, the innovation environment found in Science Parks (Albahari et al., 2018) promotes the transformation of a university's scientific research into innovative products developed by tenant firms (Díez-Vial \& Montoro-Sánchez, 2016; Westhead, 1997). Furthermore, these cooperative interactions that promote innovation occur between 
Science Park firms and the university, and between tenant firms (Bakouros et al., 2002).

Previous research on the methods used to promote the growth and development of enterprises (including those related to Science Parks) highlights the need to support firms with both configuration and process-oriented resources (Albahari et al., 2019; Autio \& Klofsten, 1998).

Configuration-oriented support, a static business support design (see Autio \& Klofsten, 1998), includes offering attractive infrastructure, reinforcing the Science Park's brand, and increasing funding availability (Albahari et al., 2019). The Science Park brand, built mainly through social networks and the internet, is one of the main values Science Parks provide tenants (Cadorin, Johansson, et al., 2017; Lam et al., 2021; Salvador, 2011) and helps attract new tenants and talent (Dabrowska, 2011; Felsenstein, 1994). A Science Park's reputation potentially increases the availability of funds as it facilitates the identification of high-quality firms. Thus, the screening activity of investors is optimised, and the risk these investors perceive is reduced. (Albahari et al., 2019; Schiavone et al., 2014).

Process-oriented support is related to offering a range of activities and services. Because Science Parks host firms of different ages, maturity and business orientations, the support the firms receive needs to address the firms' specific needs. In general, the services a Science Park provides communicates what it values and address the real needs of entrepreneurs. These services can be grouped into three broad categories: incubation, training, and networking (Albahari et al., 2019). Incubation assists firms during their first months of existence, training helps entrepreneurs develop their business ideas, and networking facilitates collaboration with strategic actors in the park. 


\subsection{Science Parks stakeholders}

The connections and relationships with the actors of the triple helix model (see Leydesdorff \& Etzkowitz, 1996) are central to the concept of Science Parks (Albahari et al., 2019; Cadorin et al., 2021; I. Guy, 1996; Quintas et al., 1992). For example, links between firms and universities are essential for the training of employees (Kesting et al., 2014; Vedovello, 1997), for the development of entrepreneurial spirit among university students, and for the exchange of knowledge and technology between academia and commercial applications (Autio et al., 2018).

Some students and researchers go beyond university boundaries and create start-ups in Science Parks (Díez-Vial \& Montoro-Sánchez, 2016; Franklin et al., 2001). These academic entrepreneurs need business advice to help them develop their ventures (Albahari et al., 2018; Cadorin, Johansson, et al., 2017; Franklin et al., 2001), physical and virtual collaboration platforms to promote open innovation and community extension principles (Kakko, 2012), and adequate business facilities (Etzkowitz \& Klofsten, 2005; Franklin et al., 2001; Lamperti et al., 2017; Walcott, 2002) such as small and inexpensive offices, incubators, and co-working spaces, to accommodate their growth (Rowe, 2014). Science Parks usually provide these essential resources (Albahari et al., 2018; Huffman \& Quigley, 2002), and the proximity to a university keeps academic entrepreneurs close to their origins, motivating the relationships between the new firm and the university and facilitating ongoing interaction (Díez-Vial \& Montoro-Sánchez, 2016; Etzkowitz \& Zhou, 2018).

The local business ecosystem found in Science Parks stimulates tenant firms to build collaborative networks with the local university and other firms (Phillimore, 1999; Silva et al., 2020) and attract talented employees (Hu, 2008; Schweer et al., 2012), which are essential in developing innovative products. Other Science Parks in the region and 
off-park firms can also influence a Science Park as well as be influenced by a Science Park (Albahari et al., 2019; Marinazzo, 1996).

Furthermore, Science Parks do not operate in isolation, nor are they concerned only with their internal relationships (Etzkowitz \& Zhou, 2018). On the contrary, several actors outside a Science Park need to be considered, whether in academic, industrial, or governmental sectors (regional, national, and international). Indeed, the local government is an essential stakeholder in the relationship network because Science Parks rely on public infrastructures such as transportation, housing, schools and medical facilities (Etzkowitz \& Zhou, 2018). Federal government authorities play an essential role in directing how Science Parks will be developed, which influences the selection of tenant firms as well as the projects pursued (Biswas, 2004). At the international level, embassies can contribute to the internationalisation of a Science Park's brand and financial institutions (both public and private) can provide the necessary financial resources to develop projects in a Science Park (Marinazzo, 1996; Silva et al., 2020).

Finally, because of this variety of actors, individual interests need to be considered, and each actor needs to work towards a common goal. On the government side, economic growth and technological development through innovation are highly coveted (Silva et al., 2020). Universities desire the results of their research to reach the market whether through patents or technology licensing (Poonjan \& Tanner, 2019). Indeed, a university's links with neighbouring tenant firms facilitate the application of academic knowledge in commercial solutions (Karlsson \& Wigren, 2012). Firms and entrepreneurs connect with universities to find projects with potential for commercialisation and a quick return, and these relationships are the expected synergies that will make a Science Park successful (Jonsson, 2002). 


\subsection{Talent}

Qualified professionals are the main factors for determining whether a firm is competitive and ultimately survives (Alnidawi et al., 2017; J. B. Barney, 1995; Holland et al., 2007). When professionals have, in addition to their experiences and specific qualifications (Gagné, 2004; Saddozai et al., 2017), the motivation to perform at the highest level, achieving remarkable results, we say that this person is a talent for a firm (Collings \& Mellahi, 2009).

Literature addresses talents from two perspectives: objects and subjects (Gallardo-Gallardo et al., 2013). Objects refer to personal characteristics, including 'ability, capacity, capability, commitment, competency, contribution, experience, knowledge, performance, and potential, patterns of thought, feeling or behaviour, and skills that are related to the characteristics of people' (ibid., p. 293). Subject refers to an elite subset of workers in a firm.

Although there is no precise definition of what constitutes talent (Lewis \& Heckman, 2006; Thunnissen et al., 2013), Gallardo et al. (2013) define talents as professionals who already deliver exceptional results (high-performing talents) or are capable of moving faster than their peers (high-potential talents), while presenting different demands, motivations, and behaviours compared to regular workers. Saddozai et al. (2017) assert that talents have skills, knowledge, creativity, professional competence, communication, and leadership ability, whereas Thunnissen, Boselie and Fruytier (2013) and Mcdonnell et al. (2017) highlight the ability of talent to add value to a firm and boost its performance. Furthermore, the organisational environment in which professionals perform their activities strongly influences the results obtained and the talent development process (Gagné, 2004; GallardoGallardo et al., 2013). Moreover, it is not possible to establish a direct correlation between previous success and expected future performance 
when working conditions are not similar (Thunnissen \& Van Arensbergen, 2015).

\subsection{Talent characteristics}

Meyers et al. (2013) describe talent as having a continuous spectrum, ranging from totally innate to fully acquired throughout life. The authors also present five main characteristics of talents found in the literature: giftedness, strength, (meta) skills, high potential, and high performance. Talents have specific experiences and abilities and are often interested in developing the firm's culture, networks, and organisational structure (Gagné, 2004; Saddozai et al., 2017). In addition to performance, professionals need to have outstanding qualifications to be considered a talented person (Thunnissen \& Van Arensbergen, 2015). Therefore, potential talents such as recent graduates, junior researchers, and novice professionals desire to improve their skills so they can become more valuable to firms (Papademetriou et al., 2008).

In summary, talent skills comprise potential, performance, creativity, competence, and leadership abilities (Saddozai et al., 2017) as well as commitment and willpower to use these skills to achieve above-average results (Gagné, 1985; Gallardo-Gallardo et al., 2013; Saddozai et al., 2017; Tansley, 2011). According to the literature (Gallardo-Gallardo et al., 2013; Saddozai et al., 2017; Tansley, 2011; Tansley \& Kirk, 2017; Thunnissen \& Van Arensbergen, 2015), the talents' main characteristics are correlated with their knowledge, skills, experiences, creativity, leadership, ability to communicate and cooperate, and motivation to act (Table 3). 
Table 3 - The main characteristics of talents

\section{Characteristics Examples}

Science \& Technology Scientific knowledge and academic expertise proficiency

Business experience Competencies, experience

Personal skills

Creativity and cognitive skills

Leadership

Leadership abilities

Social skills

Communication and cooperation skills

Behavioural aspects

Drive and motivation

\subsection{Science Park talent attraction activities}

Irrespective of the types of talent needed, younger and mature firms will benefit from talent attraction activities developed by Science Parks. On the one hand, young firms often lack technical or managerial skills and need to strengthen their staff (Bøllingtoft \& Ulhøi, 2005; De Cleyn et al., 2015; Gilley et al., 2004), but their processes, including the hunt for professionals, tend to be immature, making this search a significant challenge. Indeed, young firms are described in the literature as being more dependent on support from a Science Park (Albahari et al., 2018; Zhu \& Tann, 2005). When it comes to start-ups in their early years of development, this dependence is even more significant, and Science Park support can increase the chances of business success (De Cleyn et al., 2015). Lundqvist et al. (2014) claim that young firms that bring together entrepreneurs engaged in business development have a greater chance of better performance. Furthermore, the authors emphasise that incubators need to learn and apply effective methods to influence the formation of start-up teams. 
On the other hand, mature firms have consolidated processes and therefore are less dependent on external support (Gilley et al., 2004). However, they desire to keep their products and production processes innovative enough to guarantee their competitiveness in the market. To accomplish this, mature firms need to hire people with fresh ideas who are commonly associated with young academics and university students (Klofsten \& Jones-Evans, 1996; Kusmana, 2019). Such individuals are usually found in high concentration in Science Parks (Cheba \& HołubIwan, 2014; Ferguson \& Olofsson, 2004; Gwebu et al., 2018; Holland et al., 2007; Rowe, 2014; R. Siegel et al., 1993)

Indeed, regardless of the firm's maturity, understanding its need for talented workers and selecting the ones who are the best fit for a team has become essential for a firm's survival (Cappelli, 2008; Thunnissen et al., 2013). This issue is a subject of debate in human resource literature (Boudreau \& Ramstad, 2007; Collings \& Mellahi, 2009; Lewis \& Heckman, 2006). Talent management has gained relevance for firms (Mcdonnell et al., 2017), and its practices, which include attracting, selecting, developing, and retaining talent (Heinen \& O’Neill, 2004; Mcdonnell et al., 2017; Thunnissen et al., 2013), are considered a crucial source of competitive advantage (Collings \& Mellahi, 2009; Mcdonnell et al., 2017).

One of the inherent principles of Science Parks is supporting firms in accessing academic knowledge (Albahari et al., 2017; Lindelöf \& Löfsten, 2005; Löfsten \& Lindelöf, 2002). Science Parks establish communication channels with the local university to facilitate the training of firm workers and the recruitment of qualified labour from the academic environment (Chan \& Lau, 2005; Drejer et al., 2021; Poonjan \& Tanner, 2019; Vedovello, 1997). The opportunities for professional and personal development offered by Science Parks (Thunnissen et al., 2013) are not always easy for a firm to achieve independently (Younger et al., 2007). 
In fact, promoting the exchange of knowledge (Díez-Vial \& MontoroSánchez, 2016) and talents (Cadorin et al., 2019) between the local university and tenant firms is one of many activities performed by Science Parks. In this context, academic entrepreneurs can find in Science Parks the proper infrastructure (Albahari et al., 2019; Etzkowitz \& Klofsten, 2005; Walcott, 2002; Westhead \& Storey, 1995) and the business consultancy to make their ideas a reality (Huffman \& Quigley, 2002; Rowe, 2014).

Therefore, the availability of an innovative environment, job opportunities in high-tech firms, as well as facilities that promote a high quality of life (Cadorin et al., 2020; Chan \& Lau, 2005; Florida, 2002) enables Science Parks to help firms attract and retain talent. Finally, tenant firms have the possibility to build robust collaboration networks that make their talent management processes even more effective $(\mathrm{Hu}$, 2008; Schweer et al., 2012).

\subsection{Science Park performance}

The literature notes that each Science Park has unique objectives, carries out activities in different ways, and interacts with a diverse set of stakeholders, which complicates the development of universal criteria that can be used to measure the effectiveness of Science Parks and therefore complicating any comparisons between Science Parks (Albahari et al., 2017, 2018; Liberati et al., 2016). In fact, this heterogeneity of characteristics makes measuring the park's performance or even inferring its level of success extremely problematic (Poonjan \& Tanner, 2019).

To understand how Science Parks generate value for their tenants, studies suggest some indicators to measure the efficiency of Science Parks such as years of operation, R\&D expenses, firms' gains linked to innovation, and relationships generated with local universities (Aaboen et al., 2008; Albahari et al., 2013; Guadix et al., 2016; W.-H. Lee \& 
Yang, 2000). A report from the European Commission (Rowe, 2014) recommends other indicators such as the total and built areas of the Science Park, the number of tenant firms, the number of skilled workers, and the quality of the jobs generated. Some authors also identify partner networks as impacting the performance of Science Parks (Bigliardi et al., 2006; E. K. Guy et al., 1996; Lam et al., 2021).

These indicators assess Science Park's performance from an intrinsic point of view related to technological synergy (product-related). Nonetheless, it is also possible to evaluate from an extrinsic perspective linked to economic development (impact-related). In addition, considering that Science Parks do not produce instant results, their success indicators (intrinsic or extrinsic) require some time to pass before they are evident (Comacchio \& Bonesso, 2012; Hogan, 1996).

Moreover, the National Research Council (2009, p. 31) argues that a combination of five factors must exist in all Science Parks, although they do not guarantee success:

1. links with a university or research centre to support a critical mass of knowledge workers;

2. accessibility of funding over a sustained period;

3. a reliable and dedicated management team;

4. a physical infrastructure and quality-of-life amenities; and

5. talented and motivated individuals to produce and commercialise the knowledge generated.

In their study of three Science Parks, Koh, Koh, and Tschang (2005) identify two common success factors across parks: good access to talent and the ability to generate new technologies and products for worldwide markets. For example, the success of Silicon Valley is attributed to a series of competitive advantages, such as a broad set of technical talents, availability of pre-existing infrastructure and network of 
suppliers, available venture capital, excellent educational facilities and research institutions, and well-developed information networks that contribute to the formation of new firms (Amirahmadi \& Saff, 1993; C.-M. Lee et al., 2000).

\subsection{Research model}

This study explores how Science Parks plan and perform activities to attract talent to a Science Park and its tenant firms. This study hypothesises that the characteristics of the desired talent and the Science Park's structure, processes, characteristics, and stakeholder relationships affect a Science Park's performance. In addition, the talent attraction activities developed by Science Parks act as mediators of this influence.

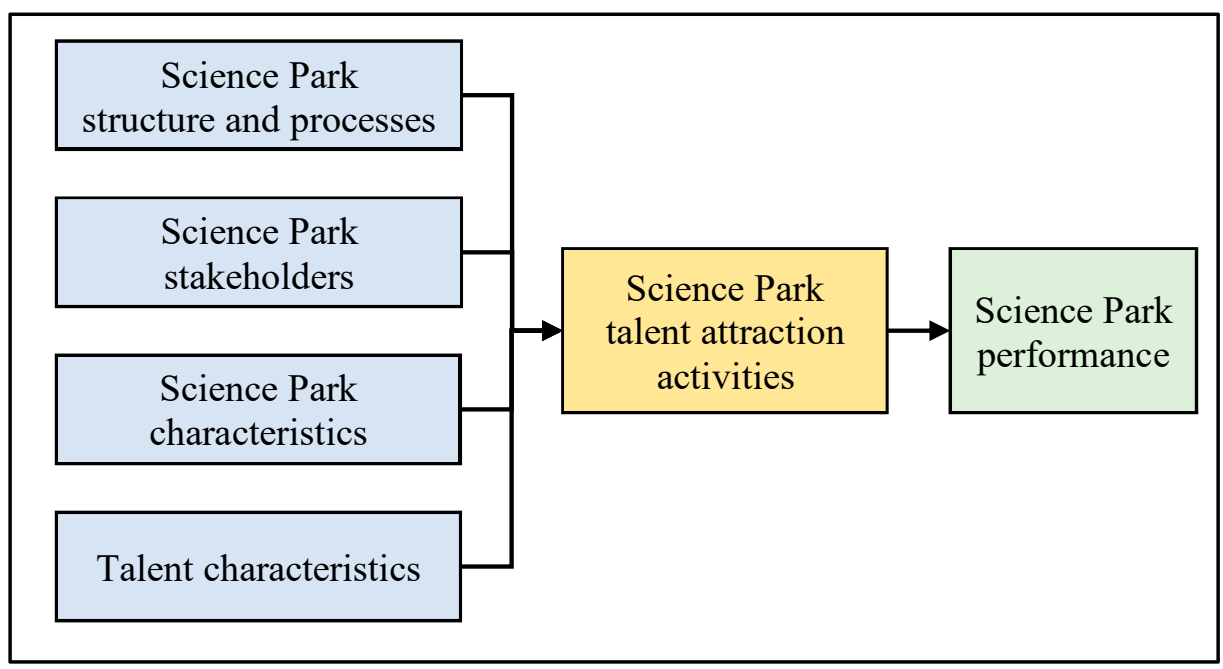

Figure 1 - Research model: the effects of talent attraction activities on Science Park performance.

First, the proposed research model (Figure 1) suggests that structure and processes of Science Parks are oriented towards configuration (attractive infrastructure, Science Park brand, and availability of 
funding) and processes (incubation, training, and networking) (Albahari et al., 2018; Autio \& Klofsten, 1998).

Second, the Science Park's stakeholders considered in this study are the triple helix model actors (see Leydesdorff \& Etzkowitz, 1996). The government provides public services such as transportation, housing, schools, and the health system; supports the Science Park's projects through public funding agencies and embassies; and demands innovative products (Cadorin, Johansson, et al., 2017; Laamanen \& Autio, 1996; Marinazzo, 1996). The academy actor is the local university, which provides knowledge, technology, training, and talent (Poonjan \& Tanner, 2019). The industry is embodied mainly by the tenant firms, incubators and start-ups, private financing firms, and even off-park firms in the region.

Third, the Science Park characteristics considered are age (year of establishment), size (number and maturity of its tenant firms and the number of employees), and location (region, proximity to universities and developed centres, and proximity between tenants) (Albahari et al., 2018; Autio \& Klofsten, 1998; Ramírez-Alesón \& Fernández-Olmos, 2018).

Fourth, the characteristics of the talents who are the targets of the Science Park attraction activities are science and technology expertise, business experience, personal skills, leadership, social skills, and behavioural aspects (Gallardo-Gallardo et al., 2013; Saddozai et al., 2017; Tansley, 2011; Tansley \& Kirk, 2017; Thunnissen \& Van Arensbergen, 2015).

Fifth, the talent attraction activities developed by Science Parks act as mediators in the research model and can be analysed in terms of the level of activity (i.e., whether the activities attract talent at the firm or individual level) or according to talent categories (i.e., activities that aim to attract talent as individuals or as a class of individuals) (Cadorin, Johansson, et al., 2017). 
Finally, the Science Park performance is based on a set of indicators found in the literature: innovation results (number of patents, number of licenses, and number of R\&D projects), the success of tenants, firmacademic links, firm-firm links, and the availability of talented and motivated individuals to produce and commercialise knowledge (Bigliardi et al., 2006; K. Guy, 1996; National Research Council, 2009; Rowe, 2014).

\subsection{Summary}

This study explores how Science Parks plan and perform activities to attract talent to a Science Park and its tenant firms. Although the literature on Science Parks is not conclusive in terms of the benefits offered to tenant firms and their characteristics, this study suggests a model to test the hypothesis that the characteristics of the desired talent and the Science Park's structures, processes, characteristics, and stakeholder relationships influence the Science Park performance as well as whether the talent attraction activities developed by Science Parks act as mediators of this influence. 


\section{METHODS AND DATA}

This chapter describes the research process and the decisions that led to this thesis and discusses the plan and approaches applied to answer the proposed research questions. The summary of the papers is then presented, highlighting the division of the work. Finally, the validity and reliability of the results are analysed, and the methodological limitations are presented.

\subsection{Research background}

The preparation for this $\mathrm{PhD}$ course began in 2013 when I attended the first executive course in innovation management promoted by the Brazilian Army in partnership with Linköping University, SAAB, and the Swedish Armed Forces. At that time, the Brazilian Army was conceiving a Science Park as one of the pillars for the planning and operationalisation of its Science, Technology, and Innovation System. This new Science Park planned to be based on the interaction between academia, government, and industry actors, following the Triple Helix model, to stimulate research, innovation, and product development for the defence sector. Therefore, to create a new Science Park, the Brazilian Army would need people with knowledge about the development of Science Parks. After some studies and conversations, Brazil and Sweden signed a bilateral strategic cooperation agreement, which included some master and $\mathrm{PhD}$ courses at Linköping University.

In 2015, I joined the course and started studying Science Parks and talent attraction issues. During the course, my professional relationship as an officer in the Brazilian Army was maintained. The initial period of the course was intensely dedicated to attending to academic disciplines to deepen and expand the horizons of knowledge. Also, I started the necessary preparation for the first scientific article on Science Parks and talent attraction, "Future developments for Science Parks: Attracting and developing talent". This article was co-authored 
with Professor Magnus Klofsten, my course supervisor, and Mr Sten Gunnar Johansson, founder and former CEO of Mjärdevi Science Park (now named Linköping Science Park) for more than 30 years. This study was initially presented at the High Technology Small Firms (HTSF) Conference on Technology-Based Entrepreneurship in Liverpool and the 33rd IASP World Conference on Science Parks and Areas of Innovation in Moscow (both in 2016). The article was published in the journal Industry and Higher Education at the beginning of 2017. This first publication confirmed that the research project was heading in the right direction, enabling me to continue my studies.

\subsection{Research design}

Nasser (2001) explains that a research design is a plan to answer the research questions proposed, and it should include a structure and strategy on what will be accomplished from the development of the hypotheses through the final analysis of data when the operational implications are identified. In addition, research designs must carefully select the most appropriate approaches for the study's final objective, and the choice should include the methodologies for data collection and the proper techniques for analysis. Bryman and Bell (2007) state that there are advantages and disadvantages in using different approaches simultaneously. Moreover, Jick (1979) and Johannessen (2009) recognise that there are gains in composing methodologies, mainly by avoiding problems related to bias, which is a common problem when using only one method.

The research design of this thesis was developed having initially a qualitative phase aimed at deepening the knowledge about Science Parks and talent attraction, and this was followed by a quantitative phase to expand and apply the qualitative phase results in a broader context. The qualitative phase identified a series of talent attraction activities that describe different aspects related to the characteristics of talent as well as related to the stakeholders, structures and processes of 
Science Parks. The results of this phase supported the formulation of the questionnaire for the quantitative stage (Sieber, 1973; Tashakkori \& Teddlie, 1998). Table 4 shows the focus of each phase of the research design.

Table 4 - Phases of the research design

\begin{tabular}{ll} 
Phase & Focus \\
\hline Literature Review & Science Parks \\
& Talent attraction \\
\hline Qualitative Case Studies & $\begin{array}{l}\text { One Science Park and four cases } \\
\text { Three Science Parks and seven } \\
\text { cases } \\
\text { One Science Park and one } \\
\text { university }\end{array}$ \\
\hline Quantitative Survey Studies & $\begin{array}{l}\text { Stakeholder collaboration and } \\
\text { talent characteristics } \\
\text { Partnerships with students/alumni } \\
\text { and universities/firms } \\
\text { Compilation of the articles and } \\
\text { analysis of the findings }\end{array}$ \\
\hline Thesis &
\end{tabular}

The literature review preceded all phases and permeated the entire process until the writing of this thesis. The qualitative phase consisted of three studies. The first study considered one Science Park and four activities to attract talent. The second involved three Science Parks and seven talent attraction activities. The third undertook a more in-depth look at the relationship between Science Parks, the tenant firms, and the local university when attracting academic talent. Each of the three qualitative studies resulted in a scientific publication. 
The quantitative phase began with planning a questionnaire and sending it to 120 European and Brazilian Science Parks. The survey encompassed economic, political, and cultural aspects, enabling an analysis of the development of Science Parks from the perspective of the activities carried out to attract talent. The quantitative phase resulted in two scientific papers.

\subsection{Research approach}

Strauss (1987) states that studies that adopt only one method are more exposed to problems such as those associated with the formulation of interview questions, biased or not entirely accurate answers. The author recommends an information triangulation approach to mitigate these risks.

Triangulation in social science was first discussed by Campbell and Fiske (1959), who believed that more than one method would guarantee the validation of a process. That is, the triangulation of information ensure valid results and not artificial products of a single method (Bouchard, 1976). Triangulation can also be applied internally by using various collection and analysis techniques to cross-reference the information obtained. However, cross-method triangulation is commonly used in research and is the one that produces the most reliable results. (Jick, 1979).

Easterby-Smith, Thorpe, and Lowe (1991) define four types of triangulation: i) triangulation of theories - the explanation of a phenomenon comes from a theory of another field of research; ii) data triangulation - data collection occurs at different times or from different sources; iii) researcher triangulation - data collection is carried out independently by different researchers; iv) methodological triangulation - the analysis of the collected data makes use of quantitative and qualitative methods. 
This research explains the influence of talent attraction activities in the development of Science Parks by adopting a methodological triangulation approach that uses the qualitative phase to develop hypotheses, which are embodied in the proposed model, to be tested in the regressions analysis of the quantitative phase (Kaplan, 2015).

This thesis uses a qualitative approach to collect data from three Swedish Science Parks. These data were used to build the theoretical frame (Yin, 2003) for Science Parks and talent attraction activities. Then, a quantitative approach was used to test the hypotheses developed during the qualitative phase and to identify causal relationships between the variables (Hart, 1998) of the international Science Park survey. Moreover, Kaplan (2015) states that surveys can validate or contextualise observations derived from cases studies.

Table 5-Aim and research approach of the papers.

\begin{tabular}{|c|c|c|}
\hline Paper & Aim & Research approach \\
\hline 1 & $\begin{array}{l}\text { To explore activities } \\
\text { developed by Science Parks } \\
\text { to stimulate the attraction of } \\
\text { talent. }\end{array}$ & $\begin{array}{l}\text { Qualitative approach: } \\
\text { Longitudinal case study on a } \\
\text { Swedish Science Park } \\
\text { through interviews and } \\
\text { secondary data. Interactive } \\
\text { research approach. }\end{array}$ \\
\hline 2 & $\begin{array}{l}\text { To examine how Science } \\
\text { Parks collaborate with } \\
\text { stakeholders to attract } \\
\text { talent. }\end{array}$ & $\begin{array}{l}\text { Qualitative approach: In- } \\
\text { depth case study on three } \\
\text { Swedish Science Parks } \\
\text { through interviews and } \\
\text { secondary data. Interactive } \\
\text { research approach. }\end{array}$ \\
\hline 3 & $\begin{array}{l}\text { To map types of interactions } \\
\text { and engagements occurring } \\
\text { between Science Parks and } \\
\text { their adjacent university to }\end{array}$ & $\begin{array}{l}\text { Qualitative approach: } \\
\text { Literature review and } \\
\text { descriptive cases to illustrate } \\
\text { the findings from the } \\
\text { literature. }\end{array}$ \\
\hline
\end{tabular}




\begin{tabular}{lll}
\hline \multicolumn{5}{c}{ attract talent discussed in } \\
the literature.
\end{tabular}

\subsubsection{Qualitative approach}

The first three studies of this research project were carried out applying a qualitative methodology to deepen the knowledge of activities undertaken by Science Parks aimed at attracting talent. The literature review for composing the cases covered studies on Science Parks, defined by academia and park associations, and talents, which are considered either an individual (subject) or individual characteristics (object).

The decision to use case studies was based on the understanding that this method is the most suitable for investigating contemporary phenomena immersed within a real-life context, especially when it is not easy to distinguish the studied phenomenon from the background (Yin, 2003). In addition, Eisenhardt and Graebner (2007) credit enormous relevance in this methodology in terms of connecting precious qualitative evidence with traditional deductive research. Also, Eisenhardt (1989) suggests that researchers should use an iterative working process when comparing empirical data with theory. 
The case studies in the three Swedish Science Parks were constructed based on interviews with key people and considering the existing context behind the analysed events (Gioia et al., 2013; Yin, 2003). Furthermore, comparing the facts observed in the case studies with the academic literature, new hypotheses emerged about the different circumstances in which talent attraction activities can occur in Science Parks.

The first study addresses the Mjärdevi Science Park (MSP), now Linköping Science Park, because during its over 30 years of operation. MSP has had some successes and some failures attracting talent. In addition, Linköping University maintains solid connections with its management team, ensuring reliable access to information.

A longitudinal case study was then conducted on the motivations and activities related to attracting talent to MSP. The MSP development timeline was subdivided into four phases: inception, start-up and early development, expansion and development, and continuous growth and development. The objectives and stakeholders of all phases were highlighted, and the talent cases that were built illustrate different aspects related to talent attraction.

In addition, Mr Sten Gunnar Johansson, founder and former CEO of MSP, participated as an active observer and provided this research project with detailed information on the development of MSP, from before its founding in 1984 until 2014 when he left the park management. In addition, one interview was conducted with the CEO of the LEAD business incubator to enrich information about processes developed by the incubator team that related to attracting talent. Secondary data were collected from associated scientific papers and institutional documentation. In accordance with the research questions, longitudinal analysis of the concepts identified in each phase included grouping and organising the concepts into patterns of activities related to talent attraction (see Gioia et al., 2013). Finally, the cases were 
validated by people who were not involved in the data collection process but had actively participated in the development of MSP.

The second study encompasses two additional Swedish Science Parks - Ideon Science Park (ISP) and Lindholmen Science Park (LSP) - with seven talent cases. These three Science Parks shared similar characteristics such as age, orientation, and location (i.e., they are in the same country and therefore share the same legislation and culture).

The data were collected through semi-structured interviews with a panel of key individuals, including former and current CEOs, incubator managers, and Science Park management members who are project leaders of talent activities. The interviews were designed to identify potential talent cases, gather historical information, validate the data, and receive feedback on the study's design (Florin et al., 2007). Furthermore, this study adopts the Science Park perspective (supplyside), so no employees of the tenant firms were interviewed (demandside). The interviews were conducted in 2015 and 2016 and comprised of 13 personal interviews lasting around 25 hours. In addition, some respondents had three follow-up telephone interviews lasting between 15 and 30 minutes. Also, the interviews held with the founding director of MSP set a research relationship similar to the interactive research approach described by Ellstrom et al. (2011), generating a bidirectional flow of information and knowledge between practice and research.

The third study reviews the literature regarding the formal and informal links between Science Parks and the local university to attract talent. The collection of readings consisted of a list taken from references of selected articles and the results of searches in the Google Scholar, Scopus, and Web of Science databases for a set of keywords. An interactive refinement process was carried out, rejecting some papers after analysing the abstract and including new ones taken from citations. The interactive process continued until the new references found were either already in our set of articles or did not contribute to the study. 
The interactions collected in the literature review were characterised by two dimensions related to the degree of formalism and alignment with a strategic objective, according to the maturity level of the tenant firm involved in the interaction.

In addition, six descriptive cases were developed to illustrate the results of the study since the relationship between Linköping University (LiU) and MSP focuses not only on the commercialisation of university knowledge but also on attracting academic talent (Cadorin, Johansson, et al., 2017). Other factors that were accounted for include MSP's close relationship with LiU for more than 30 years (Etzkowitz \& Klofsten, 2005) and that LiU and MSP share geographic, social, and cognitive forms of proximity (Boschma, 2005). For the cases, semi-structured interviews, lasting between $30 \mathrm{~min}$ and $60 \mathrm{~min}$ each, were conducted with one advisor from LiU Innovation Office, one senior advisor from Demola, and two representatives from Mjärdevi Science Park (the former and founder CEO and the current manager of Community and Employer Branding, with whom a follow-up interview was also conducted to obtain information about a new park activity and to test our theoretical model). In the end, each respondent validated the information written in the cases.

\subsubsection{Quantitative approach}

Studies 4 and 5 applied a quantitative methodology to validate the information identified in the literature and to test the results from the case studies. The statements and hypotheses drawn in these papers originated from the findings of the qualitative phase (Papers 1 to 3 ).

The preparation of these studies (Papers 4 and 5) included developing a questionnaire in two stages. First, the model was built and refined to generate questions that can be quantified. Exploratory procedures become more precise when the factors are measured using several variables in the analysis; the ideal amount of variables was between 
three and five for each element measured (MacCallum, 1990; Safón, 2009). Thus, most of the questionnaire items were measured according to Likert-type scales (1-5). Second, considering that the expected level of the respondents is equivalent to a director, president, or Science Park manager, the current and the former CEO of Linköping Science Park were asked to pre-test the questionnaire to identify ambiguities and avoid misinterpretations in the final version.

To ensure a relevant population of Science Parks in the survey and to obtain a better response rate, the International Association of Science Parks and Areas of Innovation (IASP) was invited to help conduct the survey. In December 2017, the first meeting with the IASP director general and operations director was held. The IASP team of professionals checked and reviewed the questions before being integrated into the IASP annual questionnaire "2018 IASP General Survey on Science and Technology Parks and Areas of Innovation". An entire section on talent-related issues was created in the IASP survey to incorporate the questions of this research project.

In June 2018, the questionnaire was then submitted to IASP fullmember Science Parks in Brazil and Europe and was open for responses until September 2018. IASP oversaw contacting the Science Park managers and reminding them to respond to the survey. In the end, the result was a sample with responses from 59 Science Parks (a response rate of 50.4\%): five in Brazil, one in Austria, one in Bulgaria, two in Denmark, two in Estonia, one in Finland, six in France, two in Germany, two in Greece, four in Italy, one in Latvia, one in Lithuania, two in Poland, three in Portugal, one in Serbia, one in Slovenia, six in Spain, five in Sweden, one in Switzerland, two in the Netherlands, six in Turkey, and four in the United Kingdom. In addition to the Science Parks that did not respond (58), three responses were not valid and were discarded because two were just incubators and one was just a "general contact". 
The data collected with the questionnaire were analysed using a variety of analytical methods within Statistical Package for the Social Science (SPSS) ${ }^{3}$ to verify variables' acceptability and validity. Correlation analysis performed at the variable level and the factor level identifies statistically significant measures, and regression analysis identifies the connections between dependent and independent factors.

Papers 4 and 5 explain the methodology and statistical analysis in more detail. The fourth paper strives to define the collaborations that occur regarding talent attraction processes and examined 22 variables, including eleven independent variables, five control variables, and six variables of Science Park performance - i.e., success dimensions. The fifth paper examines 25 variables, including four control variables, and aims to increase knowledge about managing talent attraction in Science Parks, having a particular focus on students and alumni of the university as human and strategic resources.

\subsection{The papers of this thesis}

3.4.1. Paper 1: Future developments for Science Parks: Attracting and developing talent.

a) Summary

Paper 1 is a qualitative study of how Science Parks can attract talent by considering stakeholders, relationships, and motivations of Science Parks. The central hypothesis of this study is that the performance of Science Parks is linked to their capacity to attract talent.

\footnotetext{
${ }^{3}$ https://www.ibm.com/analytics/spss-statistics-software
} 


\section{b) Division of work}

Paper 1 was co-written with Professor Magnus Klofsten, a full professor at Linköping University, Sweden, and my supervisor in this research project, and with Mr Sten Gunnar Johansson, a former CEO of MSP. Magnus Klofsten and I collected data from MSP and from the LEAD incubator. Sten Gunnar Johansson described the development of MSP from its founding in 1984 until recently, providing us with historical information that helped identify different talent-related cases during MSP's development.

I wrote the introduction section, which also incorporates a literature review. Magnus Klofsten offered valuable comments to guide me in the construction of the methodology section and contributed to developing the analysis and conclusion sections. Sten Gunnar Johansson also contributed by proposing many practical implications. I led the review process with the journal editors, making the requested adjustments or justifying the refusal of the proposed changes. All authors reviewed and approved the paper's final version, which was peer-reviewed by anonymous reviewers as part of the publication process in the Industry and Higher Education Journal in 2017.

\subsubsection{Paper 2: Science Parks and the attraction of talents: activities and challenges.}

a) Summary

Paper 2 is a qualitative study that explores the activities carried out by Science Parks to attract talent to their tenant firms. This study collects data from seven case studies on talent-attracting activities carried out by three Science Parks in Sweden. This study shows that the Science Parks implement many different talent attraction activities, whether looking for key personnel for start-ups or organising platforms that facilitate the establishment of firms in the park or even approaching 
academic talents as a way of making the Science Park more attractive to young talents.

b) Division of work

Paper 2 was co-written with Mr Magnus Klofsten, Mr Alberto Albahari from Universidad de Málaga, Spain, and Mr Henry Etzkowitz from Stanford University, USA. Magnus Klofsten and I collected the main data by interviewing the CEOs of the Science Parks. Under the supervision and collaboration of Magnus Klofsten, I led the writing of the Introduction, Literature Review, Method and Data, and Policy Implication sections. Magnus Klofsten guided me in the data analysis process and supported me in constructing the conclusions. Alberto Albahari made valuable contributions to the Introduction, Literature Review, and Policy Implications sections. Henry Etzkowitz provided helpful knowledge about the development of Science Parks in the world and the Triple Helix model, which was valuable for constructing a historical context for the Introduction and Literature Review sections. He also contributed to the Conclusion and Implications sections. I led the review process with the editors, making the requested adjustments or justifying the refusal of the proposed changes. All authors reviewed and approved the paper's final version, which was peer-reviewed by anonymous reviewers as part of the publication process in the Triple Helix Journal in 2020.

\subsubsection{Paper 3: Universities and Science Parks: Engagements and interactions in developing and attracting talent.}

\section{a) Summary}

Paper 3 is a qualitative study that reviews the literature on the interactions between Science Parks and universities. Talent attraction and entrepreneurship are discussed as the main structures of these interactions. This study gives more insights into concrete activities that 
Science Parks and universities develop to deliver skilled human resources for the park and the region. This study identified different types of interactions according to the maturity levels of firms. When firms are in the start-up stage, they focus more on their growth, and as they mature, they shift focus to their development.

\section{b) Division of work}

Paper 3 was co-written with Ms Eloïse Germain-Alamartine, PhD student at Linköping University, Ms Dzamila Bienkowska, Assistant Professor at Linköping University, and Mr Magnus Klofsten. I collected and analysed the literature on talents, Science Parks, and their collaboration with universities, writing the Literature Review and Method sections related to these subjects. Eloïse made identical sections in relation to the entrepreneurial university. Then, Eloïse and I conducted the interviews with personnel responsible for the illustrative cases, and I was responsible for composing the Illustrative Cases of Interactions section. Also, along with Eloïse, we created the first version of the model, which received valuable improvements from Magnus and Dzamila until it reached the final version. Eloïse and I led the review process with the editors, making the requested adjustments or justifying the refusal of the proposed changes.

Working in collaboration with another $\mathrm{PhD}$ student and professors with experience in entrepreneurial universities enabled me to deepen my theoretical knowledge about the role of the university in the formation of entrepreneurs as well as the various interactions between the university and the management of the Science Park aimed at the development of academic talents.

All authors reviewed and approved the paper's final version, which was peer-reviewed by guest editors and published in the Springer book Developing Engaged and Entrepreneurial Universities in 2019. 


\subsubsection{Paper 4: Science Parks, talent attraction and}

stakeholder involvement: an international study.

\section{a) Summary}

Paper 4 is a quantitative study of how talent characteristics and the collaborations between Science Parks and their stakeholders promote talent attraction, which may include attracting professionals with specific expertise or facilitating the establishment of foreign firms in the Science Park.

b) Division of work

Paper 4 was co-written with Professor Magnus Klofsten and Professor Hans Löfsten, full professor at Chalmers University of Technology and my assistant supervisor in this research project. With the valuable comments and suggestions from the other two authors, I developed the model tested in Papers 4 and 5. I was also responsible for the Literature Review section, and Magnus wrote the Introduction section. Professor Löfsten led the quantitative analysis and composed the corresponding part of the paper. We all worked on the Discussion, Conclusion, and Policy Implications sections. I led the review process with the editors, making the requested adjustments or justifying the refusal of the proposed changes. All authors reviewed and approved the paper's final version, which was peer-reviewed by anonymous reviewers as part of the publication process in The Journal of Technology Transfer in 2021.

\subsubsection{Paper 5: Science Parks and talent attraction management: university students as a strategic resource for innovation and entrepreneurship.}

\section{a) Summary}

Paper 5 is a quantitative study that tests another part of the research model. The purpose was to deepen knowledge about the activities 
aimed at attracting talent developed by the Science Parks, focusing on the relationship with the university and its students and alumni, all strategic resources. The study investigates how the management of the Science Parks can promote successful relationships with universities and academic talents that support the development of the tenant firms and the Science Park itself.

\section{b) Division of work}

Paper 5 was co-written with Professor Hans Löfsten (the first author) and Professor Magnus Klofsten. For the first time in this research project, I was not the first author of a paper, mainly because I had to return to Brazil and started working in parallel with the $\mathrm{PhD}$ course. As a third author, I made contributions to the Literature Review section, mainly concerning Science Parks, talent, and talent management theories. Magnus was responsible for the Introduction section. Professor Löfsten led the written process and conducted a quantitative analysis of the survey data. We worked together in the Discussion and Implications and Conclusions sections. Professor Löfsten also led the review process with the editors, making the requested adjustments or justifying the refusal of the proposed changes. All authors reviewed and approved the paper's final version, which was reviewed by anonymous reviewers as part of the publication process in the European Planning Studies journal in 2020.

\subsection{Validity and reliability}

The quality of a study can be determined by its validity and reliability. Validity can be described as the best possible estimate of the truth of a given statement or inference (Donald Thomas Campbell \& Cook, 1979). The reliability of a study is related to the stability and consistency of its results (Carmines \& Zeller, 1979), and it is guaranteed if, under identical conditions, the repetition of the study procedures provides the same result. Therefore, reliability is essentially a reduction 
of bias and errors to the minimum level (Moser \& Kalton, 1989; Yin, 2003).

\subsubsection{Qualitative studies}

Validity in qualitative studies involves ensuring the accuracy of the definitions presented, the measurements made, and the procedures applied (J. W. Creswell \& Clark, 2007). Preference was given to definitions taken from highly cited studies and renowned authors in the fields or those used by internationally recognised associations.

In the data collection for the qualitative studies, the primary resource used was interviews, which involves several subjective factors that can influence the accuracy of the information collected. To minimise such problems and increase the validity of the answers, interactive processes were adopted. For example, the interviewees were given the opportunity to comment on their responses and how the responses were categorised. That is, the interviewees were encouraged to review, comment, and revise the interview material. An undesired effect of this interactive process is that it takes a great deal of time and effort; however, this approach helps mitigate researcher bias.

Furthermore, the interviews were carried out preferably by telephone or computer video calls, guided by a previously defined structure used in all meetings. In this way, the interviews followed a semi-structured pattern that allowed collecting the same type of information with all the interviewees but giving them the freedom to add new information and suggest other people to be interviewed, a process that resembles the snowball effect mentioned by Yin (2003).

Finally, the case studies were also validated by people with extensive knowledge of the subject addressed but were not involved in the data collection phase. Thus, these validators could independently verify, comment, correct, and validate the results. In addition, the activities that 
proved unsuccessful or were ended by the Science Park for any reason are also present in the studies and therefore make this research more reliable and connected with reality (J. Creswell, 2009).

\subsubsection{Quantitative studies}

In quantitative studies, it is necessary to validate the construction and statistical analysis. Although questionnaires tend to be highly reliable and aim to guarantee data integrity, they also introduce measurement errors since the number of analytical variables that can be used is limited (Bonoma, 1985).

In the quantitative studies of this research, responses from 59 Science Parks were used, which can be considered a significant number when compared to other quantitative studies carried out on Science Parks (Albahari et al., 2018; Gwebu et al., 2018; e.g. Link \& Scott, 2006; Listyaningrum \& Van Geenhuizen, 2019). However, the selection was not entirely random since the survey was submitted only to IASP fullmember Science Parks in Brazil and Europe. Since the decision was made to work in cooperation with the IASP, a pre-selection was made, so bias was introduced and needed to be considered in the analyses. Then, the external validity of the results is restricted to a generalisation only to IASP full-member Science Parks in Brazil and Europe. Regarding internal validity, the selection bias mainly addresses the differences and similarities found in the sample. However, it is worth noting that the support from IASP resulted in an adequate number of responses to perform the statistical analysis and optimised the entire process of sending the questionnaire and following up on the responses.

\subsection{Limitations}

In any research, it is natural to have limited resources, and unexpected situations can happen during the investigation that affect the depth with which the subjects are approached or even neglecting to consider some 
aspect of the phenomenon. Also, the background of the researcher can influence the research design. That said, during the development of this thesis, we identified our assumptions and limitations as transparently as possible and noted possible corrections for consideration in future studies.

In addition, few studies address the development of Science Parks from the perspective of talent management and the collaborations with stakeholders in talent attraction processes (e.g. Guerrero \& BerbegalMirabent, 2016; Koh et al., 2005). Therefore, the research framework was built on a theoretical basis formed by several areas of information such as Science Parks, human resource management, talent, and talent management. Considering that this subject is little explored in the academic literature, other valuable areas may have been overlooked.

Although it is possible to find studies defining talent, there is no consensus in the literature regarding its definition, but the meaning presented in the context of human resources is often considered the most correct (Gallardo-Gallardo et al., 2013; Mcdonnell et al., 2017). The challenge of formulating a precise definition is probably due to the fact that talent is a subjective concept with several interpretations, so its meaning is adjusted according to the context in which the phenomenon is being studied (Florida, 2002; Tansley, 2011). For this research project, we have simplified the concept of talent to individuals who have skills, knowledge, creativity, professional competence, communication, and leadership ability (Saddozai et al., 2017) as well as have the capability or potential to contribute to the growth of the tenant firm they are linked (Mcdonnell et al., 2017; Thunnissen et al., 2013).

Science Park literature points out that it is extremely complicated to measure the performance of Science Parks or even to qualify their level of success because of their heterogeneity (Albahari et al., 2017, 2018; Poonjan \& Tanner, 2019). Each Science Park has its own characteristics 
and its objectives and therefore different motivations that result in different actions, decisions, and stakeholders. The challenge, then, is to form criteria capable of measuring all Science Parks on the same comparative scale (Albahari et al., 2017, 2018; Liberati et al., 2016). Finally, quantitative data were collected in a single moment, making it impossible to capture the evolving nature of stakeholders, activities associated with attracting talent and the performance of the Science Park. 


\section{DISCUSSION}

This chapter discusses the empirical findings of the five papers (1-5) on which the present thesis is based. Each of the following sections addresses one research question at the empirical level. In the final section, this chapter links the main empirical findings to the research questions.

\subsection{How Science Parks organise talent attraction activities}

The first research question asked how Science Parks organise talent attraction activities, whether alone or in collaboration with other actors. The papers in this thesis describe various activities that Science Parks perform to attract talent, such as creating platforms for recruiting international firms and professionals, attracting key personnel for startups, and setting up or including student collectives in new or existing business networks.

Since the inception of Science Parks, talent has been essential to their success (Paper 1). In the early developmental stages of Mjärdevi Science Park (MSP), for example, the park experienced a lack of talent and had a shortage of professionals with needed qualifications in its management team. This situation weakened the support for tenant firms and the efforts to establish soft factors such as a prestigious address (Ramírez-Alesón \& Fernández-Olmos, 2018; Storey \& Westhead, 1994) and branding (Cadorin, Johansson, et al., 2017; Lam et al., 2021; Salvador, 2011). Observation yielded the perception that stakeholder involvement in the talent attraction activities developed by MSP management was in constant evolution, and tenant needs concerning talent were revised as the number of firms recruited to MSP increased.

In order to strengthen diversity among MSP tenants, MSP (Paper 1) made efforts to consolidate the image of MSP in the international arena and organised networking activities to attract international firms 
(Papers 1 and 2). Such firms potentially bring teams of skilled workers representing a variety of qualifications and backgrounds into MSP. Such a mix of capabilities and cultures boosted the range of talents that MSP needed for networking, boundary spanning, and transfers of experiences to meet future challenges (see the discussion of "critical mass" in "Klofsten et al., 2015). Moreover, to support the entrance of these international firms, MSP offered supportive activities (Paper 2). Assistance was primarily given for business matters but also included help with immigration matters, housing, and contacts with government authorities.

The needs among new firms for talent is something that also affects how Science Parks organise their talent attraction activities (Papers 1 to 3). Most new firms in the Science Parks are spin-offs of tenant firms or transfers from the local university. The transfers coming from the university have had the support of academic entrepreneurship courses that helped students and researchers develop their business ideas and prepare them with the necessary abilities and knowledge for evolving the business and entering the incubator. Spin-offs from existing firms naturally have support from the parent firm. However, incubator startups who have had no previous assistance from a university or parent firm tend to have poorly defined processes (Rompho, 2018) and depend more on Science Park and incubator support (Zhu \& Tann, 2005) for assistance in attracting, among others, a CEO, board representatives, or IT personnel (Bøllingtoft \& Ulhøi, 2005; De Cleyn et al., 2015).

Thus, the incubators are directly involved in supporting start-ups to attract talent (Papers 1 and 2). It seems that the proximity of incubator management to the start-up team makes them best suited for designing activities that fill knowledge gaps among them. Branding and the Science Park environment may also contribute positively to supporting start-ups in building their network of contacts and attracting the proper professionals (Papers 1 and 2). 
Cases (Papers 1 and 2) have suggested that, besides bringing firms into the Science Park, another way to attract talent is to reach them directly. To this end, the Science Parks (Paper 2) develop talent attraction activities according to the type of talent desired and the maturity level of the tenant firms. Then, the Swedish Science Parks, in the cases studies (Papers 1 and 2), carried out other networking activities designed to attract qualified workers from regional, national, and international markets. For instance, a physical arena developed by one Science Park received an increasing number of visitors over the years enabling tenants to expand their networks and find new business opportunities.

Among the integration activities that MSP organised, the mediation of connections between tenants firms and nearby universities aiming to establish research links and facilitate the hiring of graduates stands out (Poonjan \& Tanner, 2019; Vedovello, 1997).

Science Park management tended to consider university students as potential talents (Florida, 1999; Thunnissen \& Van Arensbergen, 2015) and, although the geographic proximity of the Swedish Science Parks (Papers 2 and 3) with their connected universities has not always facilitated the recruitment of students, the parks developed integration initiatives for approaching student associations and connecting with university talents aiming to spread information on Science Park initiatives.

Evidence that Science Park managers are aware that encouraging closer ties between tenant firms and university students is a beneficial way of attracting potential talent comes from the survey data of 59 Science Parks (Papers 4 and 5). This initiative seems to enable students to expand their network of contacts and develop their professional skills while tenant firms have the opportunity to test students in real business situations. For example, in one case (Paper 3), Science Park management teamed up with university student organisations to host 
annual recruitment fairs, thus creating an ideal meeting ground for university students and firms of all maturity levels. The result of this approach appears to be a greater likelihood of employment upon graduation (Hommen et al., 2006).

Moreover, the findings (Papers 4 and 5) showed that the government actor seems to have a key role in promoting collaboration between firms and universities and improving innovation and technology transfer processes. Also, the government and local authorities appear to demand some requirements concerning the orientation of the Science Parks, and relationships with these authorities may allow the Science Parks to offer their tenant firms efficient policy assistance and generate a stable environment for the attraction of talents.

An initiative of a Science Park (Papers 1 and 2) to get closer to the student community was forming a student board formed by students from various academic fields. This board worked in parallel with the Science Park board, generating new perceptions and objectives for developing the Science Park and its firms. It was also noticed that incorporating younger mindsets into decisions made by the Science Park created a bidirectional flow of information. The student board members became Science Park ambassadors, spreading information on opportunities and advantages of working with the Science Park to their fellow students. In return, students' aspirations, mentalities, and innovative ideas became accessible to Science Park management.

The idea of examining university talent was expanded to include the alumni network (Paper 3). One project invited former students who had left the region after graduation to return to the Science Park. The objective was that the alumni could interact with the employees at tenant firms to propose improvements in the processes and products of the firms. The Science Park was acting on an awareness that former students often had qualifications and professional experience which could benefit the firms (Huffman \& Quigley, 2002). 


\subsection{How does collaboration with stakeholders influence Science Parks planning for talent attraction activities and their performance?}

The second research question explored how collaboration with stakeholders influences Science Parks planning for talent attraction activities and their performance. To this end, the present thesis analysed how Science Parks collaborate with various actors, mainly in university sectors and the government, and how these relationships can affect the performance of Science Parks. This thesis also discusses how stakeholder roles and talent characteristics affect the planning of talent attraction activities and influence the success of the Science Park.

Collaboration with various actors, mainly with government agencies and the local university, is crucial during the Science Park development (Paper 1). The government supported MSP in expanding its brand internationally and advertising information about its services, facilities, and opportunities. In addition, the incubator at MSP worked actively to attract leaders, managers, and other professionals to supplement startup teams. The incubators' process to attract talent to start-ups was described as being carried out in common agreement with the start-ups and based on their real needs, with special attention when the objective is to attract a new leader to the team.

Science Park management appears to promote interactions between tenant firms and the local university in order to stimulate technology transfer, create joint projects, and facilitate the attraction of academic talent (Paper 2). In particular, park management encourages the involvement of tenant firms in activities and courses promoted by the local university because they are an exceptional opportunity for tenant firms to get closer to university students and develop a relationship that involves little investment of money and time (Hjelm \& Lindahl, 2016). For example, one university course created projects based on the real problems of tenant firms where groups of university students worked 
with tenant firm employees to propose solutions (Paper 3). Such collaborations between tenant firms and the university appear to generate bonds that will contribute to the attraction of these students after their graduation (Huffman \& Quigley, 2002).

Student associations were found to be an essential actor in the communication process between a Science Park and university students (Paper 3). In collaboration with these associations, Science Park management promoted job fairs on the university campus to increase interaction between students and tenant firms at the Science Park. These fairs seem to be one way for students and firms to get to know each other better and enhance the hiring of graduates. Graduates are a source of new and innovative ideas for firms which are a positive factor in firm development and, consequently, the overall performance of the Science Park.

Another case described how the Science Park interacted with government agencies and the local university to strengthen ties with the alumni network (Paper 3). The event resulting from the collaboration between the municipality, the university, and the Science Park allowed former students to network and learn about Science Park opportunities. The main objective of the event was to convince students to return to the region; the business experience they acquired elsewhere would potentially be beneficial, contributing to the value of both small and large firms on the Science Park.

Collaborations between Science Parks and stakeholders in the government and academia for developing activities to attract talent seem mainly designed to promote innovation and efficient technology transfer processes (Paper 4). The statistical analysis found these collaborations to be positively correlated with the success of the surveyed Science Parks (Paper 4). The characteristics of the talent attracted to the tenant firms were found to be positively correlated not with technology transfer processes between the local university and 
industry but with the success of the tenant firms and the Science Park (Papers 4 and 5).

\subsection{Implications of the research findings on Science Park talent attraction activities for research and practice}

The third research question discusses the implications of the research findings on Science Park talent attraction activities for research and practice. The present thesis proposes recommendations that can help practitioners (Science Park managers, government authorities, and others involved in its development) improve policies for attracting and maintaining a steady inflow of talent into the Science Park. Researchers in the fields of Science Parks, human resource management, and talent management may also find implications for their research paths.

Among the many ways, Science Parks can contribute to the talent management process of tenants, creating an attractive environment and actively working in the search and attraction of talents (Papers 1 to 3 ). The cases in the thesis papers suggest that Science Park managers are creating opportunities for firms to interact with academia to facilitate the flow of knowledge and talent. Such interactions promote the creation of new knowledge-intensive firms (Klofsten and Lundmark 2016) and may also contribute to the growth of existing firms in Science Parks (Klofsten and Jones-Evans 2013). Collaborating with government and university actors to facilitate access to the alumni network of universities and improve the available pool of talent seems to be an important activity for anyone involved in Science Park development (Papers 3 to 5).

The government plays a role in Science Park success by providing resources for $R \& D$ projects, encouraging the relationship between industry and academia, and supporting technology transfer processes (Paper 4). The government could also support Park firms by facilitating the establishment of firms in the Science Park (Paper 2). Another 
implication of the present thesis is that, in the role of Science Park allies, government agencies such as embassies could assist in publicising Science Parks on the international stage (Paper 1). Thus, the positive implications of government involvement with Science Parks include indirect talent attraction through incoming firms, promotion of the Science Park brands internationally, and innovation support. Government involvement could therefore contribute to a more attractive environment in the Science Park.

Furthermore, Science Park managers have indicated that they support established firms entering the Science Park (Papers 1 to 3) and consider incubators as partners in helping start-ups in their talent interests (Papers 1 and 2). The case studies (Papers 1 to 3) and the statistical analyses (Papers 4 and 5) in the present thesis identified how Science Park practitioners perceive activities for attracting talent as belonging to the portfolio of services that Science Parks offer to their tenant firms. The literature indicates that good talent management practices can improve the performance of firms (Mcdonnell et al., 2017). The present thesis suggests that if Science Parks can accomplish effective talent attraction activities, the performance of the tenant firms may improve. In fact, Science Park managers seem to consider these activities as one of the services that add value and contribute to the growth of their tenant firms.

\subsection{Summary}

This chapter discussed the activities developed by the Science Parks and their interactions with stakeholders. Table 6 summarises the empirical findings of the published papers in the present thesis (Papers 1 to 5) and how they are related to the three research questions.

This thesis (Papers 1 to 3 ) showed the various activities for attracting talent developed by the Science Parks in the papers and described such activities in-depth, exploring Science Park objectives, stakeholder 
involvement, and the challenges that Science Parks faced when organising each activity.

Table 6 - The three research questions and empirical findings.

\section{Research questions (RQs) Main empirical findings}

RQ1: How do Science

Parks organise talent attraction activities, either on their own or in collaboration with stakeholders?
Science Parks seem to organise networking, supportive and integration activities to attract talent, either on their own or in collaboration with stakeholders at the business and individual levels.

Science Parks seem to organise talent attraction activities, on their own or in collaboration with stakeholders, according to the characteristics of talent desired and the tenant firms' maturity level.
RQ2: How does collaboration with stakeholders influence Science Parks planning for talent attraction activities and their performance?
Collaborations with government and academic stakeholders seem to promote innovation, strengthen Science Park branding, and facilitate academic talent attraction, contributing positively to the development of tenant firms and the performance of Science Parks.

Collaborations with government and academic stakeholders appear to increase the numbers of tenant firms and, thus, the number of available jobs, contributing positively to the performance of Science Parks. 
RQ3: What are the implications of the research findings on Science Park talent attraction activities for research and practice?
Talent attraction activities were found as one of the services offered by Science Parks and are a possible new area of research in the fields of Science Parks, human resources, and talent management.

Science Park managers seemed to consider the maturity of the tenant firms, their needs for talent, and the characteristics of the desired talent as decisive factors in planning and developing talent attraction activities.

Government agencies seem to have an essential role in supporting the links between the tenant firms and the university and in the international dissemination of the Science Park's brand.

Moreover, the data showed that stakeholder participation seems to be essential for attracting talent (Papers 4 and 5). The studied Science Parks primarily collaborate with government agencies and local universities, and these interactions seem to be fundamental to the success of talent attraction activities and positively influence the performance of Science Parks. The university connected to the parks studied in the papers plays an important role in supplying a specialised workforce of young talent who may become entrepreneurs for a generation of new ventures (Papers 2, 3 and 5). Also, links with stakeholders tend to increase the chances for the growth and success of tenant firms (Paper 4), and growing firms create a favourable environment for improving the quantity and quality of talent in the Science Park. 
Finally, each of the papers in the present thesis recommends policy implications of talent attraction activities developed by Science Parks that can be addressed in research and practice. The papers also suggest studying talent attraction activities from the perspective of human resource management and the contributions of such activities to Science Park development. Moreover, practitioners work to create an attractive environment in a Science Park, strengthen the Science Park brand, and effectively communicate with university talents. Science Park managers seemed to consider the firm's maturity level and the characteristics of the desired talent when fulfilling the talent needs of firms. Also, government authorities appeared to contribute to Science Park talent attraction by supporting innovation initiatives and the establishment of incoming firms. 


\section{CONCLUSIONS AND FUTURE RESEARCH}

This final chapter highlights the main conclusions of the present thesis and its contributions. The implications for the study of Science Parks and their practice are also discussed. This chapter concludes by identifying some limitations of the present work and outlining proposals for future research.

\subsection{Main conclusions}

The present thesis explores how Science Parks conduct activities to attract talent for themselves and their tenant firms. The discussion (chapter 4) reported how Science Parks connected young and growing firms with key personnel and management professionals from collaborating with stakeholders; supported the long-term development of new businesses through management-developed initiatives; promoted an innovative environment alone, and often in collaboration; were involved in the stakeholder-supported transfer of knowledge and talent between tenant firms and the local university.

\subsubsection{Research question 1}

Science Parks and talent management

Talent attraction activities organized by Science Parks vary depending on the maturity level of the tenant firms (Storey \& Tether, 1998). On the one hand, firms with goals primarily with regards to growth and consolidation require more experienced management to address the shortcomings of the team. Young entrepreneur-founded firms with roots in the local university and tenant firms are sources of innovation in a Science Park. However, one of their weaknesses is an initial lack of professionals in key positions (Bøllingtoft \& Ulhøi, 2005; De Cleyn et al., 2015; Zhu \& Tann, 2005). One task of Science Park management, with the park incubator acting as the support agent, is to assist such 
firms in strategic headhunting personnel via the park's extensive network of contacts, including stakeholder contacts. The recruitment process must be conducted with great sensitivity as it is focused on a specific, concrete need of the start-up and should agree with the startup team, especially when the search is for a new leader.

On the other hand, more mature firms have consolidated processes and do not rely on external support. However, they need innovation to remain competitive and thus are more in need of talents with fresh and innovative ideas (Klofsten \& Jones-Evans, 1996; Kusmana, 2019). These differences in needs also define whether talent activities are carried out in collaboration with stakeholders or solely within the framework of the Science Park.

\section{Science Parks and context}

Science Parks need to leave their footprint in the international arena to be of interest for needed talent. Of the many ways to improve the international image of a Science Park and attract talents, establishing a prestigious address (Ramírez-Alesón \& Fernández-Olmos, 2018; Storey \& Westhead, 1994) and creating image effects (Ferguson \& Olofsson, 2004; Gwebu et al., 2018) to gain recognition through social signalling (Felsenstein, 1994; Gwebu et al., 2018) and socio-cognitive effects (Wennberg \& Lindqvist, 2010) cannot be underestimated. These elements contribute to a global, positive image of the Science Park and help build an innovative environment suitable for business development, indispensable to any plan drawn up by Science Park managers for attracting talent.

Also, successfully attracting and retaining international firms and talent means, among other things, that Science Park support services minimise barriers to entry and assist in a smooth settlement in the Science Park. The purpose of the support is to help foreigners integrate into the receiving country system by assisting in areas such as housing, healthcare, schools, and taxation, and contacts with other government 
channels. These integration activities positively impact the Science Park brand, long-term relationships, and collaborations between international talent and the Science Park.

\subsubsection{Research question 2}

Science Park - stakeholder interactions

Two primary stakeholders in Science Parks are governments and universities, and the collaborations with them facilitate $R \& D$ funding (Albahari et al., 2011; Link \& Scott, 2003), supply tenant firms with talent and technology (e.g., patents) from universities, strengthen Park branding and stimulate the innovation and entrepreneurial culture in the Science Park (Hansson et al., 2005). Without such a platform and stakeholder collaborations, talent attraction activities would be less easily developed. Thus, links with government representatives and with the local university, including student body committees, provide tenant firms with vital resources such as funding, know-how, technology, and young, talented workers.

\section{Science Park performance}

The literature proposes a set of indicators for measuring Science Park performance such as innovation results, tenant success, firm-academic and firm-firm relationships, and the presence of individuals with the talent and motivation to produce and commercialise knowledge (National Research Council, 2009; Rowe, 2014). In fact, the number of successful tenant firms and the number of workers influence Science Park's performance (Guadix et al., 2016; Rowe, 2014).

Therefore, park management needs to organize activities to attract talent with the fitting characteristics for each tenant because firms that are able to fill their expertise gaps with the right skilled professionals have a greater chance of improving their organizational performance (Lu et al., 2015) and, consequently, the performance of the parks. 
Finally, the present thesis proved that the model proposed in Chapter 2 was valid. In other words, the talent attraction activities developed by the researched or observed Science Parks mediate the influence of the talent characteristics and the park's characteristics, structure, processes, and stakeholders on the Science Parks' performance.

\subsubsection{Research question 3}

\section{Implications for practice in the broader context}

This section discusses some practical implications that may guide practitioners - such as Science Park management teams, government authorities, and others involved in growing Science Parks - toward strategies that would stimulate Science Park development and success.

Talent attraction is closely linked with the degree of inspiring and challenging work that Science Park can offer. Highly inspiring and challenging work is possible when Science Park tenancy reaches critical mass (see Klofsten et al., 2015). Thus, park management should view the formation of a pool of talent as a top priority as it would serve to maintain the minimum number of professionals needed to supplement the characteristics and experiences of the talent that is already available at the Science Park. Tenant firms are then strongly motivated to innovate and develop new successful businesses. Talent attraction should consider the maturity level of the tenant firms and the characteristics of the desired talent.

To create an attractive environment for talents, Science Park branding (i.e. the strength of its name, image, and the ideas associated with it (Ferguson \& Olofsson, 2004; Gwebu et al., 2018)) is fundamental. Thus, managers should spread information about the Science Park and upcoming opportunities by organising events at the Science Park, participating in international conferences, and using online channels such as social media. 
Science Park managers can also support tenant firms by searching business networks at the Science Park for needed skilled professionals or assisting international talent and firms with obstacles unfamiliar to newcomers from abroad. The aim to reach academic talents at local universities, in student communities, and through alumni networks could be accomplished, for example, by creating an arena to bring students and Science Park decision-makers closer together or by mediating links between tenant firms and the local university to encourage technology and talent transfer.

Moreover, Science Park stakeholders play a crucial role in promoting innovation, encouraging an entrepreneurial culture and building an attractive environment for talent (Hansson et al., 2005). Therefore, strengthening engagement with stakeholders, such as the government and universities, promotes innovation in the Science Park and develops efficient technology transfer processes, driving Science Park development and justifying a public investment in Science Parks (Albahari et al., 2013).

The university linked with the Science Park is essential for supplying it with young talents that tenant firms can employ or who are able to start new ventures (Poonjan \& Tanner, 2019). Thus, Science Park managers need to work with universities to encourage courses and seminars in entrepreneurship that give tenant firms access to university talent and cutting-edge academic developments in their field.

Government actors should provide access to public services, including but not limited to transportation, security, education, and health systems (Etzkowitz \& Zhou, 2018). In return, the government can be expected to demand the development of new, innovative products that stimulate regional growth. To deliver on these expectations, Science Park managers will need to seek support from (i) public funding agencies for the development of R\&D and (ii) national embassies abroad for the 
international dissemination of information on tenant firms and the Park brand (Laamanen \& Autio, 1996; Marinazzo, 1996).

In summary, everyone involved in the management and development of Science Parks needs to actively work to strengthen the park brand and participate in the international scene. These strategies will contribute to creating an attractive environment and effectively communicate with university talents. In order to be able to maintain a critical mass of talent in the Science Park, managers should develop talent attraction activities according to firm maturity and the characteristics of the desired talent (Klofsten et al., 2015).

\section{Implications for practice within the context of my future work}

As discussed in Chapter 3, this project is part of a bilateral agreement between Brazil and Sweden that aims to deepen knowledge on the development of Science Parks. The primary beneficiary in Brazil of this study is the Army, which offered me enough support during my advanced studies.

It is worth saying that the knowledge acquired in this research project is already being put to use in Brazil, e.g., in 2017, the Brazilian Army journal "Revista Militar de Ciência e Tecnologia" published an academic paper (Cadorin, Klofsten, et al., 2017) resulting from this research project. The paper describes the development of Mjärdevi Science Park (now Linköping Science Park), in Linköping, Sweden, from its first years until its consolidation on the world stage. The indepth description of Science Parks development can serve as a model for similar initiatives that the Brazilian Army may undertake.

After three years of immersion studies at the University of Linköping, I returned to Brazil in 2018 to begin implementing the knowledge I had acquired in Sweden. Since then, the Brazilian Army Technological Innovation and Management Agency (AGITEC; Agência de Gestão e 
Inovação Tecnológica) and the Brazilian Army Military Institute of Engineering (IME; Instituto Militar de Engenharia) have increasingly made direct use of the knowledge I gained.

AGITEC is a military agency created in 2018 for conducting and coordinating the Army's innovation processes, which occur mainly at IME and the military research centres. The directive of AGITEC is to promote and guide innovation at Army organisations, coordinating the main national actors that constitute the triple helix and their projects for developing defence products. The knowledge I gained from my studies in Sweden has significantly contributed to improving human resource management in the Army and developing talent attraction processes for recruiting qualified professionals to military projects. The challenges include creating the necessary conditions to attract the appropriate talent to defence projects and reconcile differing interests between the business and military environments.

IME is the oldest engineering school in Brazil, founded in 1792 and maintained by the Brazilian Army. The Ministry of Education of Brazil recognizes the Institute as one of the best engineering schools in Brazil, and as I have a degree in engineering and completed my master's degree at this school, I am proud to say that IME is my alma mater. The application of knowledge acquired in Science Parks development, talent, innovation, and entrepreneurship over almost five years of studies involves participating as an instructor in courses and as a speaker at events at IME.

The main contribution of the present research project is to ensure that the innovative culture change in the Army environment is lasting and that current and future generations of military commanders recognise the need to create an innovative environment in $R \& D$ facilities, attract talent, and encourage firms of all sizes and maturity to work on the development of defence products. 


\subsection{Main contributions}

Chapter 1 identified two areas of knowledge gaps, namely the mechanisms through which Science Parks support tenant firms and the perspective often adopted in studies on Science Parks. This thesis contributes to clarifying these gaps.

According to Davis and Parker (1997), the contributions of a thesis to its field can include one or more of the following categories: new or improved evidence, new or improved methodology, new or improved analysis, and new or improved theory. By shedding light on how talent attraction activities influence Science Park development, the present thesis thus contributes to research on the development of Science Parks with:

1. New or improved evidence: talent attraction was introduced as a conceptual element.

2. New or improved analysis: a model was developed to include the influence of the new element, talent attraction: (i) in a supply-side perspective and (ii) as a mediator of Science Park performance.

Chapter 2 of the present thesis pointed out that Science Parks and talent management are seldom discussed together in the literature. Thus, this thesis contributes to research on Science Parks by bringing these two research areas together and evidencing talent attraction as a new conceptual element (see Bellavista \& Sanz, 2009, p. 502) essential for explaining the influence of human resources on Science Park development.

Previous studies (see Lindelöf \& Löfsten, 2003; Monck et al., 1998; Ramírez-Alesón \& Fernández-Olmos, 2018; Westhead, 1997) have often addressed the more traditional Science Park services offered to tenant firms, and the analyses are based on comparing the benefits to whether or not the firm is a Science Park tenant. Instead of viewing this 
question from the perspective of tenant firms - the demand side and the usual strategy - the present thesis approached the issue from the perspective of Science Park management (the supply side) (Albahari et al., 2011). This approach supplements previous studies by illustrating how Science Parks perceive the benefits of attracting talent to tenant firms. Surveys of managers about their attitudes toward and motivations for supporting the growth and success of their tenant firms made supply-side perceptions possible.

The model proposed in the present thesis (see Chapter 2) expands our knowledge of the mechanisms that Science Park managers use to improve performance and create value for tenant firms. The model shows that the characteristics of talents; the structure, processes, and characteristics of Science Parks; and relationships with stakeholders positively affect the development of activities for attracting talent. The model supplements existing research on Science Park development (Albahari et al., 2013, 2019; Bigliardi et al., 2006; Weng et al., 2019) by introducing talent attraction activities as mediators for Science Park performance. The model thus offers tools for analysing Science Park performance based on an understanding of how they carry out talent attraction activities. Knowing the features of a Science Park (i.e., the characteristics, structures, and processes) and its relationships with stakeholders, efficient activities for attracting talent can be designed and executed, and Science Park performance will improve. The involvement of government and university actors in talent attraction activities developed by the Science Parks can contribute to their success by promoting efficient technology transfer and innovation generation processes (Poonjan \& Tanner, 2019). Talent characteristics should receive special attention in the planning and execution of attraction activities to reach those who meet the needs of the tenant firms (Löfsten et al., 2020).

Finally, this thesis presents improved evidence and new and improved analysis which contributes substantially to the Science Park literature, 
identifying and empirically examining critical factors of Science Park performance.

\subsection{Limitations of the thesis}

The limitations of the present thesis also offer promising avenues for future research, primarily in the fields concerning Science Parks and their mechanisms for attracting talent to tenant firms. This section presents two limitations that have already been identified and proposes paths for future work.

The first limitation is qualitative in that the present thesis is based on seven cases in three Swedish Science Parks. Collecting information on Science Parks in the same country made it possible to keep some soft factors - such as economic, social, and cultural - constant and thus better identify talent attraction cases. However, the present thesis does not claim to have observed all types of talent attraction activities; other varieties of Science Park talent attraction activities than the ones discussed here most likely occur. Future studies should aim to capture other perspectives in new talent attraction cases than what the present research has found. Other types of talent attraction activities may also be identified. More cases and from other countries would enhance what is known about the characteristics, structures, and processes of Science Parks and their stakeholders; our understanding of the motivations and activities that Science Parks develop to attract talent would also increase.

A second limitation is quantitative and concerns data collection, which was based on a short period and included 59 European and Brazilian Science Parks. The present thesis was thus unable to capture the evolutionary nature of the stakeholders, the attraction of talents, and the development of Science Parks. Future studies can investigate other aspects of talent attraction activities and examine their progression over time. Longitudinal quantitative studies are desirable because they 
provide a better understanding of the interaction between dependent and independent terms over time and a better observation of possible changes in the behaviour of the respondent and the processes.

\subsection{Future research}

This thesis on the development of Science Parks addresses concepts belonging to different research areas, such as talent, talent management, and strategic management. In addition, talent management adopts insights and practices from various fields, such as human resource management, resource-based theory and capabilities (Sparrow et al., 2014). Thus, researchers can supplement the results of the present thesis with new studies that deepen the intersections between outside research fields and the development of Science Parks and talent management.

Moreover, future studies could explore the motivations and methods that Science Parks use to collaborate with their stakeholders on talent issues. For example, the university linked with the Science Park is a special stakeholder, and new studies could analyse how to support Science Parks and their links with universities better. In addition, new studies can have a qualitative or a quantitative approach and explore the extent to which the university influences the choices that tenant firms make and guides their activities to contribute to academic research or teaching.

Finally, it is highly recommended that future studies result in practical implications, improving the performance of the Science Park and all those involved in its development, and in implications for academia, enriching the literature on both Science Parks and talent management. 


\section{REFERENCES}

Aaboen, L., Lindelöf, P., \& Löfsten, H. (2008). Incubator performance: an efficiency frontier analysis. International Journal of Business Innovation and Research, 2(4), 354-380. https://doi.org/10.1504/IJBIR.2008.018585

Albahari, A., Barge-Gil, A., Pérez-Canto, S., \& Modrego, A. (2018). The influence of Science and Technology Park characteristics on firms' innovation results. Papers in Regional Science, 97(2), 253279. https://doi.org/10.1111/pirs.12253

Albahari, A., Catalano, G., \& Landoni, P. (2013). Evaluation of national science park systems: a theoretical framework and its application to the Italian and Spanish systems. Technology Analysis \& Strategic Management, 25(5), 599-614. https://doi.org/10.1080/09537325.2013.785508

Albahari, A., Klofsten, M., \& Canto, S. P. (2011). Managing a Science Park: A study of value creation for their tenants. In Triple Helix IX International Conference "Silicon Valley: Global Model or Unique Anomaly. http://scholar.google.com/scholar?hl=en\&btnG=Search\&q=intitl e:No+Title\#0\%5Cnhttp://www.leydesdorff.net/th9/Managing a Science Park A study of value creation for their tenants.pdf

Albahari, A., Klofsten, M., \& Rubio-Romero, J. C. (2019). Science and Technology Parks: a study of value creation for park tenants. Journal of Technology Transfer, 44(4), 1256-1272. https://doi.org/10.1007/s10961-018-9661-9

Albahari, A., Pérez-Canto, S., Barge-Gil, A., \& Modrego, A. (2017). Technology Parks versus Science Parks: Does the university make the difference? Technological Forecasting and Social Change, 116, 13-28. https://doi.org/10.1016/j.techfore.2016.11.012

Albahari, A., Pérez-Canto, S., \& Landoni, P. (2010). Science and Technology Parks impacts on tenant organisations: a review of literature. MPRA Paper, 41914, 29. 
Almeida, A., Afonso, Ó., \& Silva, M. R. (2020). Panacea or Illusion: An Empirical Analysis of European Science Parks in the Case of Follower Regions. Journal of Innovation Economics \& Management, $n^{\circ} 31(1), 155$. https://doi.org/10.3917/jie.pr1.0060

Alnidawi, A. A. B., Alshemery, A. S. H., \& Abdulrahman, M. (2017). Competitive Advantage Based on Human Capital and its Impact on Organizational Sustainability: Applied Study in Jordanian Telecommunications Sector. Journal of Management and Sustainability, 7(1), 64-75. https://doi.org/10.5539/jms.v7n1p64

Amirahmadi, H., \& Saff, G. (1993). Science Parks: A Critical Assessment. Journal of Planning Literature, 8(2), 107-123. https://doi.org/10.1177/088541229300800201

Arthur, W. B. (1990). "SILICON VALLEY" LOCATIONAL CLUSTERS: WHEN DO INCREASING RETURNS IMPLY MONOPOLY? In Mathematical Social Sciences (Vol. 19).

Ashton, C., \& Morton, L. (2005). Managing talent for competitive advantage: Taking a systemic approach to talent management. Strategic HR Review, 4(5), 28-31. https://doi.org/10.1108/14754390580000819

AURP. (2017). Definitions - AURP Science Park. Https://Www.Aurp.Net/What-Is-a-Research-Park. https://www.aurp.net/what-is-a-research-Park

Autio, E., \& Klofsten, M. (1998). A comparative study of two European business incubators. Journal of Small Business Management, 36(1), 30-43. https://doi.org/10.1023/a:1007941801303

Autio, E., Nambisan, S., Thomas, L. D. W., \& Wright, M. (2018). Digital affordances, spatial affordances, and the genesis of entrepreneurial ecosystems. Strategic Entrepreneurship Journal, 12(1), 72-95. https://doi.org/10.1002/sej.1266

Bakouros, Y. L., Mardas, D. C., \& Varsakelis, N. C. (2002). Science park, a high tech fantasy?: An analysis of the science parks of Greece. Technovation, 22(2), 123-128. https://doi.org/10.1016/S0166-4972(00)00087-0 
Barney, J. (1991). Firm Resources and Sustained Competitive Advantage. Journal of Management, 17(1), 99-120. https://doi.org/10.1177/014920639101700108

Barney, J. B. (1995). Looking inside for competitive advantage. Academy of Management Perspectives, 9(4), 49-61. https://doi.org/10.5465/AME.1995.9512032192

Beaudry, C., \& Swann, G. M. P. (2009). Firm growth in industrial clusters of the United Kingdom. Small Business Economics, 32(4), 409-424. https://doi.org/10.1007/s11187-007-9083-9

Bellavista, J., \& Sanz, L. (2009). Science and technology parks: habitats of innovation: introduction to special section. Science and Public Policy, $36(7)$, 499-510. https://doi.org/10.3152/030234209X465543

Berbegal-Mirabent, J., Ribeiro-Soriano, D. E., \& Sánchez García, J. L. (2015). Can a magic recipe foster university spin-off creation? Journal of Business Research, 68(11), 2272-2278. https://doi.org/10.1016/j.jbusres.2015.06.010

Bergek, A., \& Norrman, C. (2015). Integrating the supply and demand sides of public support to new technology-based firms. Science and Public Policy, 42(4), 514-529. https://doi.org/10.1093/scipol/scu072

Bigliardi, B., Dormio, A. I., Nosella, A., \& Petroni, G. (2006). Assessing science parks' performances: Directions from selected Italian case studies. Technovation, 26(4), 489-505. https://doi.org/10.1016/j.technovation.2005.01.002

Biswas, R. R. (2004). Making a technopolis in Hyderabad, India: The role of government IT policy. Technological Forecasting and Social Change, 71(8 SPEC. ISS.), 823-835. https://doi.org/10.1016/j.techfore.2004.01.009

Blau, P. M. (1970). A Formal Theory of Differentiation in Organizations. American Sociological Association, 35(2), 201218. 
Bøllingtoft, A., \& Ulhøi, J. P. (2005). The networked business incubator - Leveraging entrepreneurial agency? Journal of Business Venturing, 20(2),

265-290. https://doi.org/10.1016/j.jbusvent.2003.12.005

Bonoma, T. V. (1985). Case Research in Marketing: Opportunities, Problems, and a Process. Journal of Marketing Research, 22(2), 199-208. https://doi.org/10.1177/002224378502200209

Boschma, R. A. (2005). Proximity and innovation: A critical assessment. Regional Studies, 39(1), 61-74. https://doi.org/10.1080/0034340052000320887

Bouchard, T. J. (1976). Unobtrusive measures: An Inventory of Uses. Sociological Methods \& Research, 4(3), 267-300. https://doi.org/10.1177/004912417600400301

Boudreau, J. W., \& Ramstad, P. eterM. (2007). Beyond HR: the new science of human capital. Choice Reviews Online, 45(03), 451552-45-1552. https://doi.org/10.5860/choice.45-1552

Bozeman, B. (2000). Technology transfer and public policy: A review of research and theory. Research Policy, 29(4-5), 627-655. https://doi.org/10.1016/S0048-7333(99)00093-1

Bryman, A., \& Bell, E. (2007). Business Research Methods (2nd ed.). Oxford University Press.

Bulan, L., \& Yan, Z. (2010). Firm Maturity and the Pecking Order Theory. International Journal of Business and Economics, 9(3), 179-200.

Cabral, R. (1998). Refining the Cabral-Dahab Science Park Management Paradigm. International Journal of Technology Management, 16(8), 813. https://doi.org/10.1504/IJTM.1998.002694

Cadorin, E., Germain-Alamartine, E., Bienkowska, D., \& Klofsten, M. (2019). Universities and science parks: Engagements and interactions in developing and attracting talent. In Developing Engaged and Entrepreneurial Universities (pp. 151-169). 
Springer. https://doi.org/10.1007/978-981-13-8130-0_8

Cadorin, E., Johansson, S. G., \& Klofsten, M. (2017). Future developments for science parks: Attracting and developing talent. Industry and Higher Education, 31(3), 156-167. https://doi.org/10.1177/0950422217700995

Cadorin, E., Klofsten, M., Albahari, A., \& Etzkowitz, H. (2020). Science Parks and the attraction of talents: activities and challenges. Triple Helix, 6(1), 36-68. https://doi.org/10.1163/21971927-00601002

Cadorin, E., Klofsten, M., \& Johansson, S. G. (2017). The development of a modern Science Park: A Swedish good practise. Revista Militar de Ciência e Tecnologia, 34(1), 55-59. http://www.rmct.ime.eb.br/arquivos/RMCT_1_sem_2017/artigo6 _2017.pdf

Cadorin, E., Klofsten, M., \& Löfsten, H. (2021). Science Parks, talent attraction and stakeholder involvement: an international study. Journal of Technology Transfer, 46(1), 1-28. https://doi.org/10.1007/s10961-019-09753-w

Cai, Y., \& Liu, C. (2015). The roles of universities in fostering knowledge-intensive clusters in Chinese regional innovation systems. Science and Public Policy, 42(1), 15-29. https://doi.org/10.1093/scipol/scu018

Campbell, Donald T, \& Fiske, D. W. (1959). CONVERGENT AND DISCRIMINANT VALIDATION BY THE MULTITRAITMULTIMETHOD MATRIX. Psychological Bulletin, 56(2), 81105.

Campbell, Donald Thomas, \& Cook, T. D. (1979). Quasiexperimentation: Design \&amp; analysis issues for field settings. Chicago: Rand McNally College Publishing Company.

Cappelli, P. (2008). Talent management for the twenty-first century. Harvard Business Review, 86(3), 74-82. https://doi.org/10.1007/s10551-010-0541-y 
Carmines, E. G., \& Zeller, R. A. (1979). Reliability and validity assessment (Vol. 17). Sage publications.

Chan, K. F., \& Lau, T. (2005). Assessing technology incubator programs in the science park: the good, the bad and the ugly. Technovation, 25(10), 1215-1228. https://doi.org/10.1016/J.TECHNOVATION.2004.03.010

Cheba, K., \& Hołub-Iwan, J. (2014). How to measure the effectiveness of technology parks? The case of Poland. Ekonometria, 1(1(43)), 27-38. https://doi.org/10.15611/ekt.2014.1.02

Chen, H., \& Yu, Y. (2008). Using a strategic approach to analysis the location selection for high-tech firms in Taiwan. Management Research News, 31(4), 228-244. https://doi.org/10.1108/01409170810851311

Cohen, W. M., Nelson, R. R., \& Walsh, J. P. (2002). Links and impacts: The influence of public research on industrial R\&D. Management Science, 48(1), 1-23. https://doi.org/10.1287/mnsc.48.1.1.14273

Collings, D. G., \& Mellahi, K. (2009). Strategic talent management: A review and research agenda. Human Resource Management Review, 19(4), 304-313. https://doi.org/10.1016/j.hrmr.2009.04.001

Colombo, M. G., \& Delmastro, M. (2002). How effective are technology incubators? Evidence from Italy. Research Policy, 31(7), 1103-1122. https://doi.org/10.1016/S00487333(01)00178-0

Comacchio, A., \& Bonesso, S. (2012). Performance Evaluation for Knowledge Transfer Organizations: Best European Practices and a Conceptual Framework. In Management of Technological Innovation in Developing and Developed Countries (pp. 127152). InTech. https://doi.org/10.5772/37168

Cooke, P. (2007). Regional innovation, entrepreneurship and talent systems. International Journal of Entrepreneurship and Innovation Management, $7, \quad 117$. https://doi.org/10.1504/IJEIM.2007.012878 
Cowling, M., \& Lee, N. (2017). How entrepreneurship, culture and universities influence the geographical distribution of UK talent and city growth. Journal of Management Development, 36(2), 178-195. https://doi.org/10.1108/JMD-03-2016-0043

Creswell, J. (2009). Research design: Qualitative, quantitative and mixed methods approach. (3rd ed.). Thousand Oaks, Sage.

Creswell, J. W., \& Clark, V. L. P. (2007). Designing and conducting mixed methods research. Thousand Oaks, Sage. https://doi.org/10.1111/j.1753-6405.2007.00096.x

Dabrowska, J. (2011). Measuring the success of science parks: performance monitoring and evaluation. XXVIII IASP World Conference on Science and Technology Parks, 1-23. http://www.pmf.sc.gov.br/arquivos/arquivos/pdf/08_07_2011_16 .28.06.346a693b4baaca30ad620164d8186c1d.pdf

Davidsson, P., \& Klofsten, M. (2003). The Business Platform: Developing an Instrument to Gauge and to Assist the Development of Young Firms. Journal of Small Business Management, 41(1), 1-26. https://doi.org/doi:10.1111/1540-627X.00064

Davis, G. B., \& Parker, C. A. (1997). Writing the Doctoral Dissertation. A Systematic Approach. (2nd ed.). Barron's Educational Series.

De Cleyn, S. H., Braet, J., \& Klofsten, M. (2015). How human capital interacts with the early development of academic spin-offs. International Entrepreneurship and Management Journal, 11(3), 599-621. https://doi.org/10.1007/s11365-013-0294-z

Diez-Vial, I., \& Fernández-Olmos, M. (2017). The effect of science and technology parks on a firm's performance: a dynamic approach over time. Journal of Evolutionary Economics, 27(3), 413-434. https://doi.org/10.1007/s00191-016-0481-5

Díez-Vial, I., \& Fernández-Olmos, M. (2017). The effect of science and technology parks on firms' performance: how can firms benefit most under economic downturns? Technology Analysis and Strategic Management, 29(10), 1153-1166. https://doi.org/10.1080/09537325.2016.1274390 
Díez-Vial, I., \& Montoro-Sanchez, A. (2017). Research evolution in science parks and incubators: foundations and new trends. Scientometrics, $110(3)$,

1243-1272. https://doi.org/10.1007/s11192-016-2218-5

Díez-Vial, I., \& Montoro-Sánchez, Á. (2016). How knowledge links with universities may foster innovation: The case of a science park. Technovation, $50 / 51$, $41-52$. https://doi.org/10.1016/j.technovation.2015.09.001

Drejer, I., Østergaard, C. R., Evers, G., \& Kringelum, L. B. (2021). University-industry collaboration on innovation in Denmark: A comparative analysis with particular emphasis on Aalborg University.

Durand, R., \& Coeurderoy, R. (2001). Age, order of entry, strategic orientation, and organizational performance. Journal of Business Venturing, 16(5), 471-494. https://doi.org/10.1016/S08839026(99)00061-0

Easterby-Smith, M., Thorpe, R., \& Lowe, A. (1991). Management research: An introduction Sage (1st ed.). Sage Publications.

Eckardt, F. (2017). The multidimensional role of science parks in attracting international knowledge migrants. Regional StudieS, Regional Science, 4(1), 218-226. https://doi.org/10.1080/21681376.2017.1383181

Eisenhardt, K. M. (1989). Building Theories from Case Study Research. In The Academy of Management Review (Vol. 14, Issue 4).

Eisenhardt, K. M., \& Graebner, M. E. (2007). Theory Building from Cases: Opportunities and Challenges. The Academy of Management Journal, 50(1), 25-32. https://doi.org/Article

Ellström, P.-E., Löfberg, A., \& Svensson, L. (2011). Pedagogik i arbetslivet: Ett historiskt perspektiv. Pedagogisk Forskning $i$ Sverige. http://www.pjos.org/ojs/index.php/pfs/article/view/8037

Escorsa, P., \& Valls, J. (1996). A Proposal for a Typology of Science 
Parks. In The Science Park Evaluation Handbook (pp. 65-80).

Etzkowitz, H. (2008). The triple helix: University-industry-government innovation in action. In The Triple Helix: University-IndustryGovernment Innovation in Action (1st ed.). Routledge. https://doi.org/10.4324/9780203929605

Etzkowitz, H., \& Klofsten, M. (2005). The innovating region: Toward a theory of knowledge-based regional development. $R \& D$ Management, 35(3), 243-255. https://doi.org/10.1111/j.14679310.2005.00387.x

Etzkowitz, H., \& Zhou, C. (2018). Innovation incommensurability and the science park. $R \& D$ Management, 48(1), 73-87. https://doi.org/10.1111/radm.12266

Felsenstein, D. (1994). University-Related Science Parks - "seedbeds" or "enclaves" of innovation. Technovation, 14(2), 93-110. https://doi.org/10.1016/0166-4972(94)90099-X

Ferguson, R., \& Olofsson, C. (2004). Science parks and the development of NTBFs-location, survival and growth. The Journal of Technology Transfer, 29(1), 5-17. https://doi.org/10.1023/B:JOTT.0000011178.44095.cd

Florida, R. (1999). The Role of the University: Leveraging Talent, Not Technology. Issues in Science and Technology, 15(4), 67-73. https://doi.org/10.1086/250095

Florida, R. (2002). The Rise of the Creative Class. In Basic Books (Revisited). http://library.wur.nl/WebQuery/clc/1997698

Florida, R., \& Mellander, C. (2015). The Rise of the Global Creative Class. In The Handbook of Global Science, Technology, and Innovation (pp. 313-342).

Florin, J., Karri, R., \& Rossiter, N. (2007). Fostering Entrepreneurial Drive in Business Education: An Attitudinal Approach. Journal of Management Education, 31(1), 17-42. https://doi.org/10.1177/1052562905282023 
Folta, T. B., Cooper, A. C., \& Baik, Y. S. (2006). Geographic cluster size and firm performance. Journal of Business Venturing, 21(2), 217-242. https://doi.org/10.1016/j.jbusvent.2005.04.005

Franklin, S. J., Wright, M., \& Lockett, A. (2001). Academic and Surrogate Entrepreneurs in University Spin-out Companies. Journal of Technology Transfer, 26, 127-141. https://link.springer.com/content/pdf/10.1023\%2FA\%3A100789 6514609.pdf

Fukugawa, N. (2006). Science parks in Japan and their value-added contributions to new technology-based firms. International Journal of Industrial Organization, 24(2), 381-400. https://doi.org/10.1016/j.ijindorg.2005.07.005

Gagné, F. (1985). Giftedness and talent: Reexamining a reexamination of the definitions. Gifted Child Quarterly, 29(3), 103-112. https://doi.org/10.1177/001698628502900302

Gagné, F. (2004). Transforming gifts into talents: the DMGT as a developmental theory-a response. High Ability Studies, 15(2), 165-166. https://doi.org/10.1080/1359813042000314745

Gallardo-Gallardo, E., Dries, N., \& González-Cruz, T. F. (2013). What is the meaning of "talent" in the world of work? Human Resource Management Review, 23(4), 290-300. https://doi.org/10.1016/j.hrmr.2013.05.002

Gilley, K. M., McGee, J. E., \& Rasheed, A. A. (2004). Perceived Environmental Dynamism and Managerial Risk Aversion as Antecedents of Manufacturing Outsourcing: The Moderating Effects of Firm Maturity. Journal of Small Business Management, 42(2), 117-133. https://doi.org/10.1111/j.1540627x.2004.00101.x

Gillmor, C. S. (2004). Fred Terman at Stanford: Building a discipline, a university, and silicon valley. Stanford University Press. https://books.google.com/books?hl=pt-

$\mathrm{BR} \& 1 \mathrm{r}=\& \mathrm{id}=\mathrm{JJKgq} 1 \mathrm{YCkeAC} \& \mathrm{oi}=$ fnd $\& \mathrm{pg}=\mathrm{PR} 7 \& \mathrm{dq}=$ Fred + Ter man+at+Stanford:+Building+a+discipline,+a+university,+and+Si 
licon+Valley\&ots=wGomwKliF4\&sig=tyKT5qxgSHVbUQClfzpjd6Le8g

Gioia, D. A., Corley, K. G., \& Hamilton, A. L. (2013). Seeking Qualitative Rigor in Inductive Research: Notes on the Gioia Methodology. Organizational Research Methods, 16(1), 15-31. https://doi.org/10.1177/1094428112452151

Gower, S., \& Harris, F. (1996). Evaluating British science parks as property investment opportunities. Journal of Property Valuation and Investment, 14(2), 24-37. https://doi.org/10.1108/14635789610112646

Gower, S. M., \& Harris, F. C. (1994). The Funding of, and Investment in, British Science Parks. Journal of Property Finance, 5(3), 7-18. https://doi.org/10.1108/09588689410078557

Guadix, J., Carrillo-Castrillo, J., Onieva, L., \& Navascués, J. (2016). Success variables in science and technology parks. Journal of Business Research, 69(11), 4870-4875. https://doi.org/10.1016/j.jbusres.2016.04.045

Guerrero, A., \& Berbegal-Mirabent, J. (2016). University research parks: What is their real effect on university research outputs? https://2016.economicsofeducation.com/user/pdfsesiones/088.pdf

Gulbrandsen, M., \& Slipersæter, S. (2007). The third mission and the entrepreneurial university model. In Universities and Strategic Knowledge Creation: Specialization and Performance in Europe (pp. 112-143). https://doi.org/10.4337/9781847206848.00011

Guy, E. K., Hogan, B., Laamanen, T., \& Marinazzo, M. (1996). The Science Park Evaluation Handbook. In Technopolis (XIII). http://www.technopolisgroup.com/resources/downloads/reports/098a_EVALMETH_fina l.pdf

Guy, I. (1996). A look at Aston Science Park. Technovation, 16(5), 217-218. https://doi.org/10.1016/0166-4972(96)00002-8

Guy, K. (1996). Designing a Science Park Evaluation. In The Science 
Park Evaluation Handbook European Innovation Monitoring System (EIMS) (Issue 61, pp. 8-28).

Gwebu, K. L., Sohl, J., \& Wang, J. (2018). Differential performance of science park firms: an integrative model. Small Business Economics, 1-19. https://doi.org/10.1007/s11187-018-0025-5

Gyurkovics, J., Lukovics, M., Buzás, N., \& Lukovics, M. (2014). Generations of Science Parks in the Light of Responsible Innovation. Responsible Innovation., August, 193-208. http://publicatio.bibl.uszeged.hu/7325/1/download.php_docID=40283

Hansson, F. (2007). Science parks as knowledge organizations - The "ba" in action? European Journal of Innovation Management, 10(3), 348-366. https://doi.org/10.1108/14601060710776752

Hansson, F., Husted, K., \& Vestergaard, J. (2005). Second generation science parks: from structural holes jockeys to social capital catalysts of the knowledge society. Technovation, 25(9), 10391049. https://doi.org/10.1016/J.TECHNOVATION.2004.03.003

Harper, J. C., \& Georghiou, L. (2005). Foresight in innovation policy: Shared visions for a science park and business-university links in a city region. Technology Analysis \& Strategic Management, 17(2), 147-160. https://doi.org/10.1080/09537320500088716

Hart, W. B. (1998). What is intercultural relations. The Edge: The EJournal of Intercultural Relations, 1(3).

Heinen, J. S., \& O'Neill, C. (2004). Managing talent to maximize performance. Employment Relations Today, 31(2), 67-82. https://doi.org/10.1002/ert.20018

Hjelm, O., \& Lindahl, M. (2016). Roles of Academia in Supporting Eco-design in Small Companies for Better Environmental and Economic Performance. Procedia CIRP, 50, 745-750. https://doi.org/10.1016/j.procir.2016.04.094

Hobbs, K. G., Link, A. N., \& Scott, J. T. (2017). Science and technology parks: an annotated and analytical literature review. Journal of 
Technology Transfer, 42(4), 957-976. https://doi.org/10.1007/s10961-016-9522-3

Hogan, B. (1996). Evaluation of science and technology parks: the measurement of success. In The Science Park Evaluation Handbook (pp. 86-97).

Holland, P., Sheehan, C., \& De Cieri, H. (2007). Attracting and retaining talent: exploring human resources development trends in Australia. Human Resource Development International, 10(3), 247-262. https://doi.org/10.1080/13678860701515158

Hommen, L., Doloreux, D., \& Larsson, E. (2006). Emergence and growth of Mjärdevi Science Park in Linköping, Sweden. European Planning Studies, 14(10), 1331-1361. https://doi.org/10.1080/09654310600852555

$\mathrm{Hu}, \mathrm{T}$. S. (2008). Interaction among high-tech talent and its impact on innovation performance: A comparison of Taiwanese science parks at different stages of development. European Planning Studies, $16(2)$, 163-187. https://doi.org/10.1080/09654310701814462

Huang, K. F., Yu, C. M. J., \& Seetoo, D. H. (2012). Firm innovation in policy-driven parks and spontaneous clusters: The smaller firm the better? Journal of Technology Transfer, 37(5), 715-731. https://doi.org/10.1007/s10961-012-9248-9

Huffman, D., \& Quigley, J. M. (2002). The role of the university in attracting high tech entrepreneurship: A Silicon Valley tale. The Annals of Regional Science, 36(3), 403-419. https://doi.org/10.1007/s001680200104

Huselid, M. A. (1995). The Impact of Human Resource Management Practices on Turnover, Productivity, and Corporate Financial Performance. In Source: The Academy of Management Journal (Vol. 38, Issue 3).

IASP. (2017). Definitions - IASP Science Park. Http://Www.Iasp.Ws/Our-Industry/Definitions. http://www.iasp.ws/Our-industry/Definitions 
Jick, T. D. (1979). Mixing Qualitative and Quantitative Methods: Triangulation in Action. Administrative Science Quarterly, 24(4), 602. https://doi.org/10.2307/2392366

Johannessen, J.-A. (2009). A systemic approach to innovation: The interactive innovation model. Kybernetes, 38(1), 158-176. https://doi.org/10.1108/03684920910930330

Jonsson, O. (2002). Innovation processes and proximity: The case of IDEON firms in Lund, Sweden. European Planning Studies, 10(6), 705-722. https://doi.org/10.1080/0965431022000003771

Kakko, I. (2012). The Fundamentals of Third Generation Science Park Concept. http://www.iftf.org/our-

Kaplan, S. (2015). Mixing quantitative and qualitative research. In Handbook of Qualitative Organizational Research: Innovative Pathways and Methods (pp. 455-465). Routledge. https://doi.org/10.4324/9781315849072

Karlsson, T., \& Wigren, C. (2012). Start-ups among university employees: The influence of legitimacy, human capital and social capital. In Journal of Technology Transfer (Vol. 37, Issue 3, pp. 297-312). https://doi.org/10.1007/s10961-010-9175-6

Kesting, T., Kliewe, T., \& Baaken, T. (2014). Impact in universitybusiness cooperation - theoretical perspectives and future directions. International Journal of Technology Transfer and Commercialisation, 13(1-2), 1-9. https://www.researchgate.net/profile/Thomas_Baaken/publicatio n/283464078_Impact_in_university-business_cooperation__theoretical_perspectives_and_future_directions/links/563a5dce0 8ae337ef29844d2.pdf

Klofsten, M. (1994). TECHNOLOGY-BASED FIRMS: CRITICAL ASPECTS OF THEIR EARLY DEVELOPMENT. Journal of Enterprising Culture, 02(01), 535-557. https://doi.org/10.1142/s0218495894000148

Klofsten, M., Bienkowska, D., Laur, I., \& Sölvell, I. (2015). Success factors in cluster initiative management: mapping out the "big 
five." Industry and Higher Education, 29(1), 65-77. https://doi.org/10.5367/ihe.2015.0237

Klofsten, M., \& Jones-Evans, D. (1996). Stimulation of technologybased small firms, a case study of university-industry cooperation. Technovation, 16(4), 187-213.

Klofsten, M., \& Jones-Evans, D. (2013). Open learning within growing businesses. European Journal of Training and Development, 37(3), 298-312. https://doi.org/10.1108/03090591311312750

Klofsten, M., \& Lundmark, E. (2016). Supporting new spin-off ventures-experiences from a university start-up program. In Academic Spin-Offs and Technology Transfer in Europe: Best Practices and Breakthrough Models (pp. 93-107).

Koh, F. C. C., Koh, W. T. H., \& Tschang, F. T. (2005). An analytical framework for science parks and technology districts with an application to Singapore. Journal of Business Venturing, 20(2), 217-239. https://doi.org/10.1016/j.jbusvent.2003.12.002

Kusmana, A. (2019). The Analysis of the Effect of Entrepreneurship Education, Perceived Desirability, and Entrepreneurial SelfEfficacy on University Students' Entrepreneurial Intention. Universal Journal of Educational Research, 7(11), 2507-2518. https://doi.org/10.13189/ujer.2019.071131

Laamanen, T., \& Autio, E. (1996). Evaluation of Tenant Evaluation and Selection Systems. In The Science Park Evaluation Handbook (pp. 110-128).

Lam, L. N. H., Nguyen, P. V., Le, T. B., \& Tran, K. T. (2021). An Analytic Hierarchy Process Approach to Marketing Tools Selection for Science and Technology Parks. SHS Web of Conferences, 92, 02045. https://doi.org/10.1051/shsconf/20219202045

Lamperti, F., Mavilia, R., \& Castellini, S. (2017). The role of Science Parks: a puzzle of growth, innovation and R\&D investments. Journal of Technology Transfer, 42(1), 158-183. https://doi.org/10.1007/s10961-015-9455-2 
Lee, C.-M., Miller, W. F., Hancock, M. G., \& Rowen, H. S. (2000). The Silicon Valley Edge: A Habitat for Innovation and Entrepreneurship. Stanford University Press.

Lee, W.-H., \& Yang, W.-T. (2000). The cradle of Taiwan high technology industry development--Hsinchu Science Park (HSP). Technovation, 20(1), 55. http://search.ebscohost.com/login.aspx?direct=true\&db=bth\&AN $=2702625 \&$ lang $=$ pt-br\&site=ehost-live

Lewis, R. E., \& Heckman, R. J. (2006). Talent management: A critical review. Human Resource Management Review, 16(2), 139-154. https://doi.org/10.1016/j.hrmr.2006.03.001

Leydesdorff, L., \& Etzkowitz, H. (1996). Emergence of a Triple Helix of university-industry-government relations. Science and Public Policy, 23(5), 279-286. https://doi.org/10.1093/spp/23.5.279

Liberati, D., Marinucci, M., \& Tanzi, G. M. (2016). Science and technology parks in Italy: main features and analysis of their effects on the firms hosted. Journal of Technology Transfer, 41(4), 694-729. https://doi.org/10.1007/s10961-015-9397-8

Lindelöf, P., \& Löfsten, H. (2003). Science Park Location and New Technology-Based Firms in Sweden - Implications for Strategy and Performance. Small Business Economics, 20(3), 245-258. https://doi.org/10.1023/A:1022861823493

Lindelöf, P., \& Löfsten, H. (2005). Academic versus corporate new technology-based firms in Swedish science parks: An analysis of performance, business networks and financing. International Journal of Technology Management, 31(3-4), 334-357. https://doi.org/10.1504/ijtm.2005.006638

Link, A. N. (2016). Competitive advantages from university research parks. In The Oxford handbook of local competitiveness (pp. 337344).

https://books.google.com/books?hl=pt$\mathrm{BR} \& 1 \mathrm{r}=\& \mathrm{id}=\mathrm{HRExCgAAQBAJ} \& \mathrm{oi}=\mathrm{fnd} \& \mathrm{pg}=\mathrm{PT} 401 \& \mathrm{dq}=\% 22 \mathrm{C}$ ompetitive+advantages+from+university+research+parks $\% 22 \& 0$ 
ts=GhG-E6Mt1x\&sig=ehGIvjxmiuMnSPnPHEIHeMPIvoc

Link, A. N., \& Scott, J. T. (2003). U .S. science parks: the diffusion of an innovation and its effects on the academic missions of universities. International Journal of Industrial Organization, 21, 1323-1356. www.elsevier.com

Link, A. N., \& Scott, J. T. (2006). U.S. university research parks. Journal of Productivity Analysis, 25(1), 43-55. https://doi.org/10.1007/s11123-006-7126-X

Link, A. N., \& Scott, J. T. (2018). Geographic Proximity and Science Parks. In Oxford Research Encyclopedia of Economics and Finance.

https://doi.org/10.1093/acrefore/9780190625979.013.272

Listyaningrum, E., \& Van Geenhuizen, M. (2019). Unravelling social capital value in science parks: Growth versus $R \& D$ orientation. 2, 1170-1177. https://doi.org/10.34190/ECIE.19.094

Löfsten, H., Klofsten, M., \& Cadorin, E. (2020). Science Parks and talent attraction management: university students as a strategic resource for innovation and entrepreneurship. European Planning Studies, 28(12), 2465-2488. https://doi.org/10.1080/09654313.2020.1722986

Löfsten, H., \& Lindelöf, P. (2002). Science Parks and the growth of new technology-based firms-academic-industry links, innovation and markets. Research Policy, 31(6), 859-876. https://doi.org/10.1016/S0048-7333(01)00153-6

Lu, C. M., Chen, S. J., Huang, P. C., \& Chien, J. C. (2015). Effect of diversity on human resource management and organizational performance. Journal of Business Research, 68(4), 857-861. https://doi.org/10.1016/j.jbusres.2014.11.041

Luger, M. I., \& Goldstein, H. A. (1991). Technology in the garden: research parks and regional economic development. In Chapel Hill (Vol. 29, Issue 08). University of North Carolina Press. https://doi.org/10.5860/choice.29-4620 
Lundqvist, M. A. (2014). The importance of surrogate entrepreneurship for incubated Swedish technology ventures. Technovation, 34(2), 93-100.

https://doi.org/10.1016/J.TECHNOVATION.2013.08.005

MacCallum, R. C. (1990). The Need for Alternative Measures of Fit in Covariance Structure Modeling. Multivariate Behavioral Research, 25(2), 157-162. https://doi.org/10.1207/s15327906mbr2502_2

Marinazzo, M. (1996). Science park evaluation and organizational analysis. In The Science Park Evaluation Handbook (pp. 81-85).

Massey, D. B., Quintas, P., \& Wield, D. (2003). High-tech fantasies: science parks in society, science and space. Routledge. https://doi.org/10.4324/9780203169360

McCann, B. T., \& Folta, T. B. (2011). Performance differentials within geographic clusters. Journal of Business Venturing, 26(1), 104123. https://doi.org/10.1016/j.jbusvent.2009.04.004

Mcdonnell, A., Collings, D. G., Mellahi, K., \& Schuler, R. (2017). Talent management: a systematic review and future prospects. European J. International Management, 11(1), 86-128. http://epe.rutgers.edu/sites/default/files/images/ejim11105_mcdo nnell_et_al.pdf

Mellander, C., \& Florida, R. (2011). Creativity, talent, and regional wages in Sweden. The Annals of Regional Science, 46(3), 637660. https://doi.org/10.1007/s00168-009-0354-z

Meyers, M. C., van Woerkom, M., \& Dries, N. (2013). Talent - Innate or acquired? Theoretical considerations and their implications for talent management. Human Resource Management Review, 23(4), 305-321. https://doi.org/10.1016/j.hrmr.2013.05.003

Minguillo, D., \& Thelwall, M. (2015). Research excellence and university-industry collaboration in UK science parks. Research Evaluation, 24(2), 181-196. https://doi.org/10.1093/reseval/rvu032 
Monck, C. S. P., Porter, R. B., Quintas, P., Storey, D. J., \& Wynarczyk, P. (1998). Science Parks and the Growth of High Technology Firms. In Croom Helm.

Moser, C. A., \& Kalton, G. (1989). Survey methods in social investigation. Routledge. https://books.google.com/books?hl=ptBR\&lr=\&id=Pk1BDgAAQBAJ\&oi=fnd \&pg=PT9\&dq=Moser,+ C.+A.+and+Kalton,+G.+(1989)+Survey+Methods+in+Social+In vestigation,+England:+Gower.+\&ots=nyjDZraT7q\&sig=JxJ6JftZ kjg2XYBakzoYxWppoxk

Moussa, M., Bright, M., \& Varua, M. E. (2017). Investigating knowledge workers' productivity using work design theory. International Journal of Productivity and Performance Management, 66(6), 822-834. https://doi.org/10.1108/IJPPM-082016-0161

Nasser, F. M. (2001). Selecting an Appropriate Research Design. In Research pathways: Writing professional papers, theses, and dissertations in workforce education (pp. 91-106). https://www.researchgate.net/publication/321491126

National Research Council. (2009). Understanding Research, Science and Technology Parks: Global Best Practices: Report of a Symposium (C. W. Wessner (ed.); Vol. 1). National Academies Press.

Papademetriou, D. G., Somerville, W., \& Tanaka, H. (2008). Talent in the 21 st -Century Economy (Issue November). http://www.migrationpolicyinstituteeurope.org/sites/default/files/publications/Talent.pdf

Phillimore, J. (1999). Beyond the linear view of innovation in science park evaluation. An analysis of Western Australian Technology Park. Technovation, 19(11), 673-680. https://doi.org/10.1016/S0166-4972(99)00062-0

Poonjan, A., \& Tanner, A. N. (2019). Science and Technology Parks and Regional Contextual Factors: A Systematic Literature Review. https://orbit.dtu.dk/ws/files/190786649/Science_and_Technology 
_Parks_and_Regional_Contextual_Factors_A_Systematic_Litera ture_Review_preliminary_study.pdf

Quintas, P., Wield, D., \& Massey, D. (1992). Academic-industry links and innovation: questioning the science park model. Technovation, 12(3), 161-175. https://doi.org/10.1016/01664972(92)90033-E

Ramírez-Alesón, M., \& Fernández-Olmos, M. (2018). Unravelling the effects of Science Parks on the innovation performance of NTBFs. Journal of Technology Transfer, 43(2), 482-505. https://doi.org/10.1007/s10961-017-9559-y

Roldan, L. B., Hansen, P. B., \& Garcia-Perez-De-Lema, D. (2018). The relationship between favorable conditions for innovation in technology parks, the innovation produced, and companies' performance A framework for an analysis model. Innovation \& Management Review, 15(3), 286-302. https://doi.org/10.1108/inmr-05-2018-0027

Rompho, N. (2018). Operational performance measures for startups. Measuring Business Excellence, 22(1), 31-41. https://doi.org/10.1108/MBE-06-2017-0028

Rowe, D. N. E. (2014). Setting up, managing and evaluating EU Science And Technology Parks: An advice and guidance report on good practice. https://doi.org/10.2776/73401

Saddozai, S. K., Hui, P., Akram, U., Khan, M. S., \& Memon, S. (2017). Investigation of talent, talent management, its policies and its impact on working environment. Chinese Management Studies, 11(3), 538-554. https://doi.org/10.1108/CMS-10-2016-0206

Sadeghi, M. E., \& Sadabadi, A. A. (2015). Evaluating Science Parks Capacity to Create Competitive Advantages: Comparison of Pardis Technology Park and Sheikh Bahaei Science and Technology Park in Iran. International Journal of Innovation and Technology Management, 12(06), 1550031. https://doi.org/10.1142/S0219877015500315

Safón, V. (2009). Measuring the Reputation of Top US Business 
Schools: A MIMIC Modeling Approach. Corporate Reputation Review, 12(3), 204-228. https://doi.org/10.1057/crr.2009.19

Salter, A. J., \& Martin, B. R. (2001). The economic benefits of publicly funded basic research: A critical review. Research Policy, 30(3), 509-532. https://doi.org/10.1016/S0048-7333(00)00091-3

Salvador, E. (2011). Are science parks and incubators good "brand names" for spin-offs? The case study of Turin. Journal of Technology Transfer, 36(2), 203-232. https://doi.org/10.1007/s10961-010-9152-0

Schiavone, F., Meles, A., Verdoliva, V., \& Del Giudice, M. (2014). Does location in a science park really matter for firms' intellectual capital performance? Journal of Intellectual Capital, 15(4), 497515. https://doi.org/10.1108/JIC-07-2014-0082

Schweer, M., Assimakopoulos, D., Cross, R., \& Thomas, R. J. (2012). Building a Well-Networked Organization. MIT Sloan Management Review, 53(2), 35-42. https://www.researchgate.net/profile/Dimitris_Assimakopoulos/p ublication/282184508_SMR_winter2012_53211/links/5606ac150 8ae8e08c0905932/SMR-winter2012-53211.pdf

Sieber, S. D. (1973). The Integration of Fieldwork and Survey Methods. In Source: American Journal of Sociology (Vol. 78, Issue 6).

Siegel, D. S., Westhead, P., \& Wright, M. (2003). Assessing the impact of university science parks on research productivity: Exploratory firm-level evidence from the United Kingdom. International Journal of Industrial Organization, 21(9), 1357-1369. https://doi.org/10.1016/S0167-7187(03)00086-9

Siegel, R., Siegel, E., \& Macmillan, I. C. (1993). Characteristics distinguishing high-growth ventures. Journal of Business Venturing, 8(2), 169-180. https://doi.org/10.1016/08839026(93)90018-Z

Silva, S. E., Venâncio, A., Silva, J. R., \& Gonçalves, C. A. (2020). Open innovation in science parks: The role of public policies. Technological Forecasting and Social Change, 151, 119844. 
https://doi.org/10.1016/j.techfore.2019.119844

Sparrow, P., Scullion, H., \& Tarique, I. (2014). Strategic talent management:future directions. In Strategic Talent Management. Cambridge University

https://eprints.lancs.ac.uk/id/eprint/67408/

Press.

Squicciarini, M. (2008). Science Parks' tenants versus out-of-Park firms: Who innovates more? A duration model. Journal of Technology Transfer, 33(1), 45-71. https://doi.org/10.1007/s10961-007-9037-z

Squicciarini, M. (2009). Science parks: Seedbeds of innovation? A duration analysis of firms' patenting activity. Small Business Economics, 32(2), 169-190. https://doi.org/10.1007/s11187-0079075-9

Storey, D. J., \& Tether, B. S. (1998). Public policy measures to support new technology-based firms in the European Union. Research Policy, 26(9), 1037-1057. https://doi.org/10.1016/S00487333(97)00058-9

Storey, D. J., \& Westhead, P. (1994). An Assessment of Firms Located On and Off Science Parks in the United Kingdom. University of Illinois at Urbana-Champaign's Academy for Entrepreneurial Leadership Historical Research Reference in Entrepreneurship. https://ssrn.com/abstract $=1510008$

Strauss, A. L. (1987). Qualitative analysis for social scientists. Cambridge University Press. https://books.google.com/books?hl=pt-

BR\&lr=\&id=y16ww5ZsJ0AC\&oi=fnd\&pg=PA109\&dq=Strauss, + A.+(1987)+Qualitative+Analysis+for+Social+Scientists, + Camb ridge: + Cambridge + University + Press. $+\& o t s=g W b B M Y g c k Q \& s i$ $\mathrm{g}=$ ybjgn5QOGCkCDSx5EZm_2ryTS-0

Sun, S. L., Zhang, Y., Cao, Y., Dong, J., \& Cantwell, J. (2019). Enriching innovation ecosystems: The role of government in a university science park. Global Transitions, 1, 104-119. https://doi.org/10.1016/j.glt.2019.05.002 
Svensson, P., Klofsten, M., \& Etzkowitz, H. (2012). An Entrepreneurial University Strategy for Renewing a Declining Industrial City: The Norrköping Way. European Planning Studies, 20(4), 505-525. https://doi.org/10.1080/09654313.2012.665616

Tansley, C. (2011). What do we mean by the term "talent" in talent management? Industrial and Commercial Training, 43(5), 266274. https://doi.org/10.1108/00197851111145853

Tansley, C., \& Kirk, S. (2017). You've Been Framed-Framing Talent Mobility in Emerging Markets. Thunderbird International Business Review, 1-13. https://doi.org/10.1002/tie

Tashakkori, A., \& Teddlie, C. (1998). Mixed methodology: Combining qualitative and quantitative approaches (Vol. 46). Sage Publications. Applied Social Research Methods Series; Volume 46.

Thunnissen, M., Boselie, P., \& Fruytier, B. (2013). A review of talent management: "infancy or adolescence?" International Journal of Human Resource Management, 24(9), 1744-1761. https://doi.org/10.1080/09585192.2013.777543

Thunnissen, M., \& Van Arensbergen, P. (2015). A multi-dimensional approach to talent. Personnel Review, 44(2), 182-199. https://doi.org/10.1108/PR-10-2013-0190

UKSPA. (2017). Definitions - UKSPA Science Park. Http://Www.Ukspa.Org.Uk/Our-Sector.

http://www.ukspa.org.uk/our-sector

Vasquez-Urriago, A. R., Barge-Gil, A., \& Rico, A. M. (2016). Which firms benefit more from being located in a Science and Technology Park? Empirical evidence for Spain. Research Evaluation, 25(1), 107-117. https://oi.org/10.1093/reseval/rvv033

Vásquez-Urriago, Á. R., Barge-Gil, A., Rico, A. M., \& Paraskevopoulou, E. (2014). The impact of science and technology parks on firms' product innovation: empirical evidence from Spain. Journal of Evolutionary Economics, 24(4), 835-873. 
https://doi.org/10.1007/s00191-013-0337-1

Vedovello, C. (1997). Science parks and university-industry interaction: Geographical proximity between the agents as a driving force. Technovation, 17(9), 491-531. https://doi.org/10.1016/S0166-4972(97)00027-8

Walcott, S. M. (2002). Chinese Industrial and Science Parks: Bridging the Gap. The Professional Geographer, 54(3), 349-364. https://doi.org/doi:10.1111/0033-0124.00335

Weng, X. H., Zhu, Y. M., Song, X. Y., \& Ahmad, N. (2019). Identification of Key Success Factors for Private Science Parks Established from Brownfield Regeneration: A Case Study from China. International Journal of Environmental Research and Public Health, 16(7), 1295. https://doi.org/10.3390/ijerph16071295

Wennberg, K., \& Lindqvist, G. (2010). The effect of clusters on the survival and performance of new firms. Small Business Economics, 34(3), 221-241. https://doi.org/10.1007/s11187-0089123-0

Westhead, P. (1997). R\&D "inputs" and "outputs" of technology-based firms located on and off science parks. $R \& D$ Management, 27(1), 45-62. https://doi.org/10.1111/1467-9310.00041

Westhead, P., \& Storey, D. J. (1995). Links between higher education institutions and high technology firms. Omega, 23(4), 345-360. https://doi.org/10.1016/0305-0483(95)00021-F

Wilson, N., Wright, M., \& Kacer, M. (2018). The equity gap and knowledge-based firms. Journal of Corporate Finance, 50, 626649. https://doi.org/10.1016/j.jcorpfin.2017.12.008

Yang, C. H., Motohashi, K., \& Chen, J. R. (2009). Are new technologybased firms located on science parks really more innovative?: Evidence from Taiwan. Research Policy, 38(1), 77-85. https://doi.org/10.1016/j.respol.2008.09.001

Yin, R. K. (2003). Case Study Research: Design and Methods (3rd ed.). 
Sage Publications. Applied Social Research Methods Series; Volume 5.

Younger, J., Smallwood, N., \& Ulrich, D. (2007). Developing Your Organization's Brand as a Talent Developer. Human Resource Planning, $30(2)$, 21-29. http://search.proquest.com/openview/0f0552c78097b6407bdb89f b9aed0e1c/1.pdf?pq-origsite $=$ gscholar\&cbl=52465

Youtie, J., \& Shapira, P. (2008). Building an innovation hub: A case study of the transformation of university roles in regional technological and economic development. Research Policy, 37(8), 1188-1204. https://doi.org/10.1016/j.respol.2008.04.012

Zhu, D., \& Tann, J. (2005). A regional innovation system in a smallsized region: A clustering model in Zhongguancun Science Park. Technology Analysis \& Strategic Management, 17(3), 375-390. https://doi.org/10.1080/09537320500211789 
104 


\section{PART II: PAPERS}




\section{Papers}

The papers associated with this thesis have been removed for copyright reasons. For more details about these see:

http://urn.kb.se/resolve?urn=urn:nbn:se:liu:diva-179118 


\section{FACULTY OF SCIENCE AND ENGINEERING}

Linköping Studies in Science and Technology, Dissertation No. 2170, 2021

Department of Management and Engineering

Linköping University

SE-581 83 Linköping, Sweden

wWw.liu.se

This project has received funding from the National Council for Scientific and Technological Development (CNPq), Brazil. 